\title{
3 The architecture of crime and fear of crime
}

\author{
Research evidence on lighting, \\ CCTV and CPTED features ${ }^{1}$
}

\section{Vania Ceccato}

\subsection{Introduction}

Urban design shapes the built environment and the types of human activities that take place in it. A safe environment is one that maximizes the use of public places with a mix of users carrying out a variety of routine activities; it is a place that encourages social interaction. A safe environment depends on what happens in this place, and what happens in it depends on how safe it is perceived to be. Lighting is essential for feeling safe in a place (Green, Perkins, Steinbach, \& Edwards, 2015; Johansson, Rosen, \& Kuller, 2011), but the impact on safety of other environmental features, such as security technologies, is less obvious (Lorenc et al., 2013; Lum, Stoltz, Koper, \& Scherer, 2019). For some people the presence of a closed-circuit television camera (CCTV) reduces their confidence, while others feel empowered and safe (Koskela, 2002; Yavuz \& Welch, 2010). So what makes a public place safe?

The aim of this chapter is to discuss the evidence in the international literature of the effects of urban design on safety-in particular, the relationship between features such as lighting and CCTV to the occurrence of crime and/or individuals' safety perceptions. Potential unexpected side effects of these features on a city's overall quality are also discussed.

To achieve these goals, the literature from 1968 to 2018 was searched, using as references the Scopus, Web of Science and JSTOR databases. Bibliometric visualization software was used to manage and map the vast material, spanning more than five decades of research, on crime and fear of crime and to answer the following questions.

- Does urban design, indicated by crime prevention through environmental design (CPTED) features, have any impact on crime and/or safety perceptions, and if so, how?

- Does lighting and/or CCTV have any effect on crime, and if so, what are the mechanisms? Are safety perceptions affected by lighting and/or CCTV, and if so, what are the mechanisms?

- Is there any risk (or "side effect") when prioritizing safety over other sustainability goals? 
The literature overview focuses on particular features of accessible public places (streets, parks, etc.) and neighborhood structure, because it is at this scale that crime and fear take shape. In addition, it is at this scale that the impact of planning decisions is experienced and planning solutions can be implemented. Finally, it is also at this scale that many safety problems can be addressed through inclusive policies by direct involvement of local stakeholders (police, safety experts, community groups) and those voices normally excluded from planning decisions.

The decision to focus this literature overview on lighting and CCTV was taken because the international literature has been strongly dominated by these features in recent decades (Painter \& Farrington, 1994; Piza, Welsh, Farrington, \& Thomas, 2019; Quinet \& Nunn, 1998; Ratcliffe, Taniguchi, \& Taylor, 2009; Sutton \& Wilson, 2004; van Rijswijk \& Haans, 2018; Welsh \& Farrington, 2009; Williams \& Johnstone, 2000).

This chapter is structured as follows. First, the importance of assessing the stateof-the-art research is introduced with a focus on urban design, crime and safety. Then methods are reported, followed by the results. In the final section, gaps in the literature and suggestions for a research agenda close the chapter. Note that in this study "public places" and "public spaces" will be used interchangeably.

\subsection{Public places, urban design and safety}

"Public space" (or here "public place") means a space legally open and accessible without the permission of anyone else, such as a common (Németh, 2012). In reality, most public spaces are conditionally "free", because action allowed in these spaces falls within the law of the locality in which the space is located. Accessibility is thought to be a basic characteristic of these places. Yet, although public spaces/places might be accessible to everyone, why is it that safety in these places may not be attainable by all?

First, safety is a function of the way one perceives these places, so an individual's fears depend on her/his individual characteristics: physical and psychological abilities, age, gender, ethnic background, sexual and socioeconomic statuses (Box, Hale, \& Andrews, 1988; Garofalo \& Laub, 1979; Pain \& Smith, 2008). It is also these characteristics (individually or intersectionally) that determine an individual's risk of victimization of crime. Although men are more victimized by crime in public places, it is women who fear public places the most (Ferraro, 1996; Pain, 1997).

Second, as previously suggested, safety also depends on what happens in these public places, and what happens in them depends on how safe these places are perceived to be. Loukaitou-Sideris and Eck (2007) indicated that walking and cycling are greatly influenced by what happens in streets and other public spaces. Safe public places invite outdoor activities, including daily walks. Poor maintenance or signs of physical deterioration of an area are thought to be more important determinants of fear of crime than the actual incidence of crime. Either way, fear may inhibit people from using a public place or lead them to avoid certain times of the day (Gray, Jackson, \& Farrall, 2011; Jackson \& Gray, 2010). Wilson and Kelling (1982) suggested that acts of vandalism and public disorder 
function as symbols of the extent to which an area is in decline, which might affect subsequent levels of crime and safety perceptions.

Third, public places are often contested places where individuals relate to rules conduct and publicness (Smith \& Low, 2013). The right to feel safe rests on a thin equilibrium between place users of all types and what Eck (2019) called "place managers", they are those people and organizations that are physically and legally able to prevent crime in a place. Each public place bears a certain morality that defines what can be done in it (under or beyond the rule of law). This morality also determines those who are the "legitimate users" (Knutsson, 1997) and those who are not.

Finally, public places vary in their levels of crime and/or in the way they are perceived. Crime and fear of crime are different phenomena. What makes a place criminogenic does not necessarily make it unsafe, and vice versa (e.g., Ceccato \& Lukyte, 2011; Ferraro, 1995; Gray, Jackson, \& Farrall, 2008; LaGrange, Ferraro, \& Supancic, 1992; Pain, MacFarlane, \& Turner, 2006). This fact has implications for both research and practice, because the root causes of crime are often not those that affect people's poor safety perceptions of a place, although they may share similar triggers. Because the environment plays an important role in affecting victimization and/or shaping fears, we focus in this chapter on environmental factors that have a direct impact on crime occurrence and fear.

As suggested in Chapter 2, poorly designed and managed built environments can create opportunities for crime and make people feel unsafe (Clarke, 2012; Crowe, 2000; Jongejan \& Woldendorp, 2013; Monchuk, 2011; Reynald, 2011). A safe environment is the one that maximizes the use of public places by a mix of users with different routine activities; it is a place that encourages social interaction, increases visibility and surveillance by passers-by and, as a result, reduces the risk of crime. Crime is less likely to occur in places where there are clear, welldefined routes and people can easily enter and leave, a place that avoids barriers and obstacles. In addition, public places that are well managed and maintained generally feel safer and encourage people to use them; they exhibit "ownership". This in turn encourages activity and natural surveillance. As indicated in Chapter 2, these principles are well encapsulated by CPTED (Crowe, 2000) and in principles of routine activity (Cohen \& Felson, 1979; Felson, 2002) and Situational Action Theory (e.g. Wikström \& Treiber, 2017).

Although the international literature shows much evidence for the effect of CPTED features on safety, the evidence is mixed; for a review, see Cozens, Saville, and Hillier (2005), Cozens and Love (2015) and Farrington and Welsh (2002). Building on these previous reviews of the literature, this chapter aims to contribute to the evidence in this area by collecting and systematizing scholarly knowledge on the effect of urban design on urban safety-in particular, the impact of features such as lighting and CCTV on crime and/or perceived safety.

\subsection{Data and methods}

The literature search covered 50 years, from 1968 to 2018 , of publications in the databases Scopus, Web of Science and JSTOR. The bibliographic selection 
was conducted in two steps: first, we focused on the bibliometric analysis and then on in-depth analysis of the material as described in sections. This is a review of literature inspired by the principles of the Cochrane Handbook for Systematic Reviews (Higgins \& Green, 2011) as well as the PRISMA checklist (Moher, Liberati, Tetzlaff, \& Altman, 2009). One of the features that distinguish this type of review from others is the pre-specification of studies following a set of eligibility criteria (Higgins \& Green, 2011). In this case, we considered both quantitative and qualitative analysis. This means that some studies did not focus on causal links between urban design and crime only but included studies of a more qualitative character typical in the planning literature. We also extended our search of articles to fear of crime and to reports. This opened up for evidence beyond the European and North American literature.

The bibliometric analysis included 4,730 articles obtained and selected from the databases (in *.ris) in different stages. VOSviewer version 1.6.12 (www. vosviewer.com) is a free-access software tool that was used to create bibliometric maps based on the keywords cited in each selected article and to group the terms in clusters according to their linkages (van Eck \& Waltman, 2019). The criterion of a minimum of two repetitions criterion aimed at avoiding terms without links or with weak links to the theme and, secondly, ensuring terms were covered and articles were representative. Output files from the database were used to produce informative network maps by theme. A number of themes were selected based on the clusters that emerged from the literature and are discussed in Section 3.4, Figure 3.1.

These themes supported the selection of topics that were thought to be relevant for further investigation in an in-depth analysis of the 106 articles (Figure 3.2). The effect of, for instance, lighting on crime and/or safety was assessed in four ways: lighting has a positive effect, namely, reducing crime and/or increasing perceived safety; lighting has a negative effect on crime and or perceived safety, namely, increasing crime and reducing safety perceptions. Inconclusive/conflicting effect was when the different, contradictory effects were observed and finally, no effect/difference, when no statistically significant impact was found on crime and/or fear of crime. The analysis also checked whether there was any relationship between lighting and crime and/or fear of crime and the location of the study area by continent.

Note that the types of methods and datasets used in the analysis covering 106 publications (35 on lighting, 22 on CCTV and 49 on CPTED) varied greatly, even among the quantitative pieces, which makes it difficult to strictly compare effects. Various studies showed that the effect of lighting, for example, on safety was dependent on crime types, levels and contexts. In addition, the search of the literature focused on public places in general and encompassed a variety of environments, from open streets to shopping malls. The analysis was based instead on a comparative assessment of the author's declared findings and conclusions in each publication. Caution is therefore necessary when drawing conclusions. 

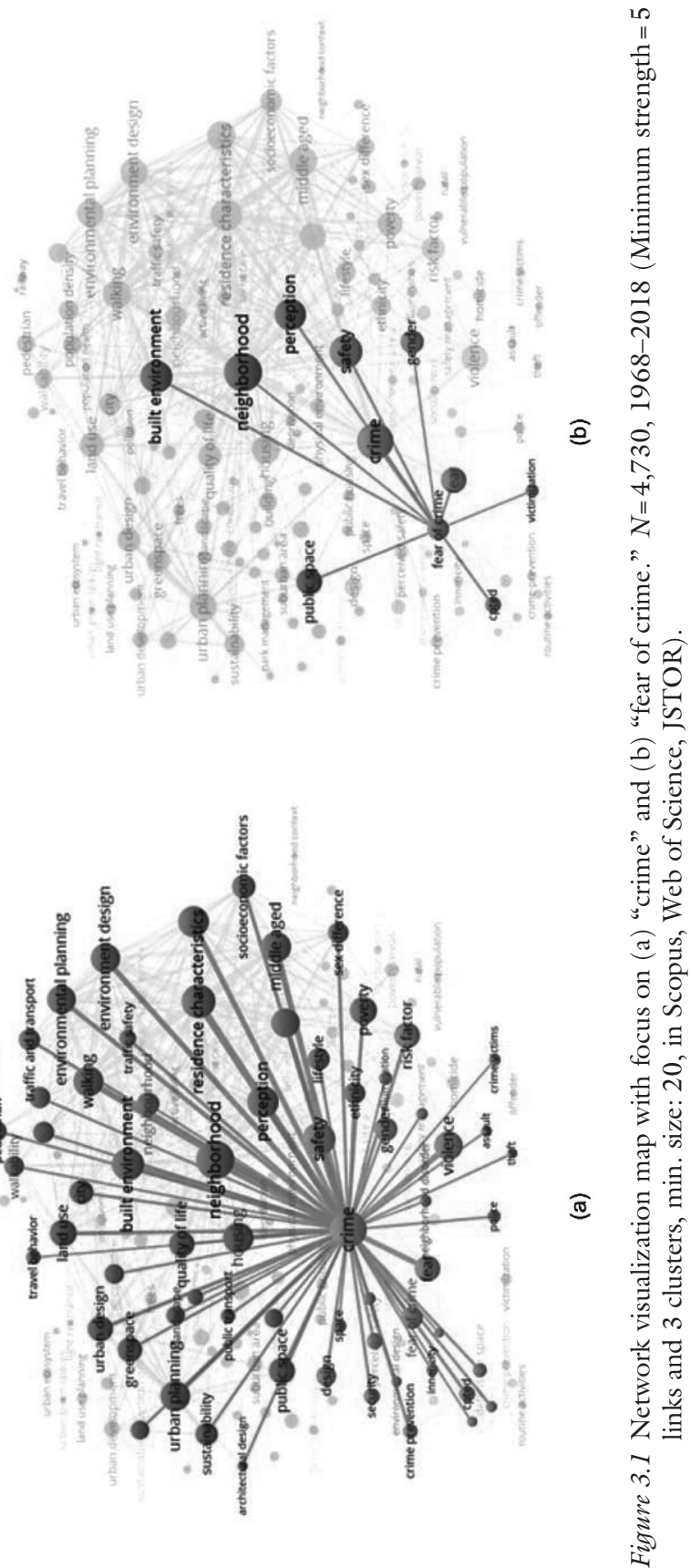


\subsection{Results and discussion}

\section{Overall bibliometric trends}

Internationally, research in this area has significantly increased in the past three decades. The bibliometric analysis for both crime and fear of crime resulted in three clusters as an outcome of the literature search based on 4,730 articles. Figure 3.1(a) shows a cluster associated with crime and victimization; another cluster with neighborhood and socio-economic conditions; and another one, which refers to studies on urban planning and landscape of the city. The greater the weight of an item by level of importance, the larger the circle. The distance between two keywords indicates the relatedness of the keywords, in terms of co-citation links. Note that there are many more articles on crime linking these three clusters than for the articles on fear of crime (Figure 3.1(b)). This complexity is not found when "fear of crime" is visualized as the focus, and articles on "built environment" are relatively "far" from "fear of crime" when compared with articles dealing with "crime".

The in-depth analysis revealed that there were 37 studies showing the effect of lighting (69 percent) out of 53 archived articles from the international literature: 72 percent of them found a positive impact of lighting on crime and/or fear (Appendix, Table A3.1). These articles were mostly published between 1998 and 2018, with a peak in 2008 (from 1968-2019), from Western Europe and the United States, but also from Asia and South America (Figure 3.2). In terms of methodology, 23 were classified as quantitative pieces, eight qualitative articles and four mixed methods. In the next section, some of the most important studies, starting from those dating back to the late 1980s and early 1990s (Griswold, 1984; Painter \& Farrington, 1994; Poyner \& Webb, 1987), will be discussed in detail.

As for CCTV, 67 percent of 22 articles (out of 63 that were selected, Appendix, Table A3.2) show that this technology had a reductive effect either on crime or perceived safety, the great majority of them in Europe and the United States. Of these, half were quantitative studies, about a quarter used mixed methods and the remainder used qualitative analysis, most revealing some effect on safety perceptions. Similar to the findings of Welsh and Farrington (2004) that CCTV had an effect only for car parks (in a data metaanalysis of 41 studies), this review showed that one quarter of the articles either showed no effect of CCTV or were inconclusive, with mixed results.

Some studies used one or various CPTED principles together to assess safety (Appendix, Table A3.3, these were selected using CPTED in the keyword, in the title or abstract). Although 65 percent of them indicated some positive impact on either crime or safety perceptions, they evaluated different aspects of CPTED and varied greatly in method and how rigorous they were performed, so caution is necessary when drawing conclusions. A bit more than half of them (27 articles) were composed of studies devoted to the importance of the physical environment and spatial arrangement as the core of the analysis. Only four included aspects of city livability, health and sustainability issues, and the remainder included aspects of community engagement and social cohesion or 


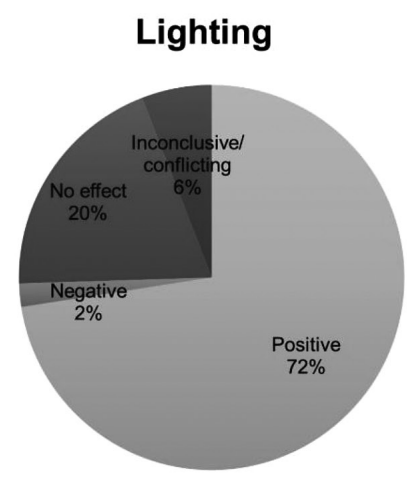

$N=35$ articles out of 51 selected $(69 \%)$

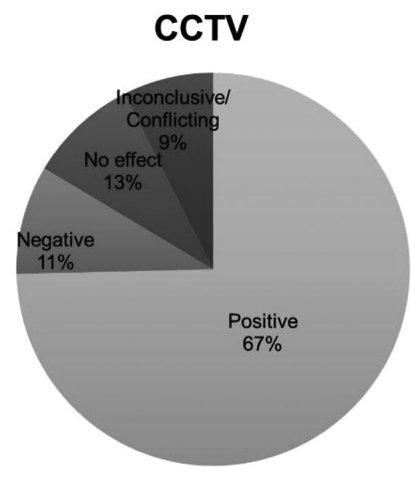

$N=22$ articles out of 63 selected $(35 \%)$

\section{CPTED features}

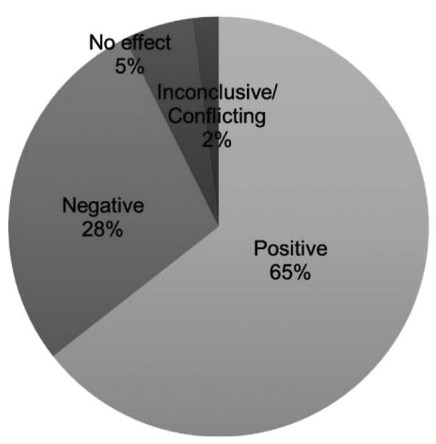

$N=49$ articles out of 135 selected $(36 \%)$
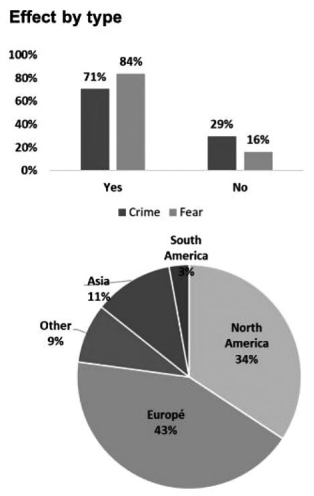

Effect by type
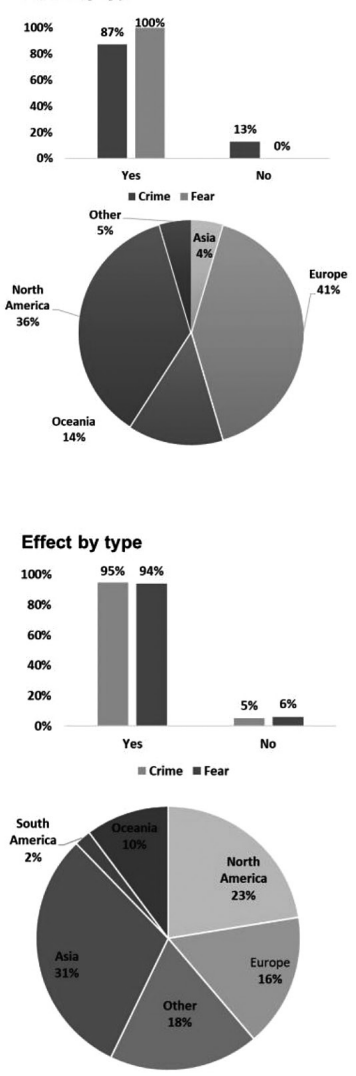

Figure 3.2 Effect of lighting, CCTV and CPTED features on crime and fear of crime according to the international literature 1968-2018. $N=106$ articles. 
user's perspective. Figure 3.2 summarizes the characteristics of publications that link crime and fear to CPTED principles, CCTV and lighting.

\section{The effect of lighting on crime and fear}

There is no other feature of urban space that is more controversial with regards to its effect on safety than lighting. Lighting is thought to improve safety perceptions, but previous research shows that its effect on crime is conflicting (Cozens, Neale, Whitaker, Hillier, \& Graham, 2003; Green et al., 2015; Lawson, Rogerson, \& Barnacle, 2018; Painter \& Farrington, 1994). Although there has been evidence that introducing street lighting reduces road traffic collisions and crimes, there was no evidence of any increase in crime or accidents where street lighting was reduced at night (Perkins, Steinbach, \& Tompson, 2015). Traditionally, it is believed that modifying nighttime visibility in urban areas should affect opportunities for crime by increasing the perceived risk of offender detection, or, alternatively, lighting increases the chances for certain types of crimes by making victims more visible: the "fishbowl effect". At the same time, an improvement of street lighting may have an extra indirect effect. Residents are believed to invest more in their community and show that people in that area are in control, encouraging potential offenders to find other areas that are "less risky" in terms of detection. What does this literature overview indicate?

Out of 35 articles, the overall effect of illumination on crime is positive: 72 percent of studies show that (good) lighting has a positive effect on safety, in other words reduces crime and/or fear of crime. Such an effect is slightly more prominent on perceived safety than on crime occurrence (Figure 3.2, see effect by type: crime and fear). These results reflect a diverse flora of studies, with different methods, types of crime, safety perception indicators and geographical contexts. For example, crimes vary greatly by type, from theft and robbery as well as less frequent offenses with very different mechanisms and records, such as violent crimes, homicides, police calls for service and total crime. The spectrum of urban environments varies widely, too, from large cities to rural communities as well as computer-generated landscapes, but the reductive effect is consistent.

After several small-sample analyses in the United Kingdom, the seminal study by Atkins, Husain, and Storey (1991) broke fresh ground by showing that better street lighting had little or no effect on crime. However, they also found that the improved street lighting was warmly welcomed by the public and that it provided a measure of reassurance to some people, particularly women, who were fearful in their use of public space. The study by Herbert and Davidson (1994) examining the impact of improved street lighting upon crime and community safety in two British cities also concluded that perceived safety was increased by improved street lighting, although similar effects on crime rates were difficult to assess. Mixed effects were also found in Japan for property crimes, by Takizawa, Koo, and Katoh (2010), in the United States, by Groff and McCord (2012), and by Cozens, Neale, Whitaker, Hillier and 
Graham (2003) and all these three studies suggest further research on the effect of street lighting on crime.

Among studies that found crime reduction in association with lighting, Quinet and Nunn (1998) reported on an evaluation of the effects of streetlights on crime in several neighborhoods in Indianapolis. Also in the United States, Loomis, Marshall, Wolf, Runyan, and Butts (2002) found that bright exterior light was associated with reduction of homicides in workplaces. Byun and $\mathrm{Ha}$ (2016) found that lighting was associated with the reduction of burglaries in Seoul, South Korea. Peek-Asa and Casteel (2010) indicated that good lighting presents a reduction of total robbery, controlling for a number of factors in the retail setting. In a rural context in the Global South, the study by Arvate, Falsete, Ribeiro, and Souza (2018) showed that better lighting is associated with a decrease in homicides. Farrington and Welsh (2002) reported a systematic review incorporating meta-analytic techniques of the effects of improved street lighting on crime to indicate that good lighting has a positive effect on crime reduction. More intriguing was the study by Stolzenberg, D'Alessio, and Flexon (2017) who investigated the effect of moon illumination on reported crime occurring outdoors between the hours of $10 \mathrm{pm}$ and $2 \mathrm{am}$ in 13 US states, as well as the District of Columbia. Findings showed that moonlight had a reductive effect on outdoor crime, though no significant influence on indoor crimes and total crime. In addition, in England and Wales, Skudder et al. (2018) showed that external and internal lighting were effective and also had a small carbon footprint.

In terms of safety perceptions, there is positive evidence of the effect of lighting, but some of the studies are also inconclusive. It is important to keep in mind that these articles are based on different methods with varied statistical rigor and large differences in sample sizes. In Ohio, in the United States, Tseng, Duane, and Hadipriono (2004) showed that lighting was the most significant factor in determining the quality of users' perceptions of parking garages. In Sweden, where the winters are dark and long, Tjoa and Devon (2010) showed how illumination in a Swedish city positively affected perceived safety and influenced accessibility, walking and cycling. Also in Sweden, Johansson, Pedersen, Maleetipwan-Mattsson, Kuhn, and Laike (2014) found a positive effect of lighting on accessibility and perceived safety. Yet another study in Sweden, by Lindgren and Nilsen (2012), confirmed the importance of good illumination in relation to greenery in residential areas. In a qualitative study by Pain et al. (2006) in the United Kingdom, findings showed that individual's reports are complex and reflective about the influence of lighting on crime and fear.

There were a number of experimental studies to test the effect of lighting on safety. Using artificial urban scenes, Stamps (2005) found that the perception of safety was strongly correlated with the lightness of the scene. Using computer-generated urban scenes, Nikunen and Korpela (2012) found that lighting had a positive effect on overall fear, while Haans and de Kort (2012) demonstrated that people prefer having light in their own immediate surroundings rather than on the road that lies ahead. Also using computer-generated 
landscapes, Nasar and Bokharaei (2017) found that uniform lighting would be judged more appealing or safer than would non-uniform lighting, but its effects are uncertain. Using a simulation analysis in South Korea, Kim and Park (2017) found that increased illuminance could not be linked to an improvement in pedestrians' visibility or perceptions of safety because many factors were thought to be important to be considered for a real improvement in visibility. An interesting study was performed by van Rijswijk and Haans (2018) in which participants reported increased perception of safety in improved lighting environments after an evaluation of 100 pictures of different streets at night in the Netherlands. Using real-time data, Castro-Toledo, Perea-Garcia, BautistaOrtuno, and Mitkidis (2017) assessed fear in urban public space in Spain, Denmark and the United States and found that lack of good lighting was associated with psychological reactions of arousal related to fear, and heart rates collected seemed to sustain that finding.

The type of lighting and its impact on safety perceptions was the focus of a number of studies in particular settings, with mixed results, such as university campuses, bridges and roads (De Boer, Heylen, \& Teeuw, 2014; Fotios, 2016; Fotios, Unwin, \& Farrall, 2015; Haans \& de Kort, 2012; Kim \& Noh, 2018). Others focused on the effect of lighting in transit environments (Chandra, Jimenez, \& Radhakrishnan, 2017; Ferrer, Ruiz, \& Mars, 2015; Green et al., 2015; Rankavat \& Tiwari, 2016; Srisuwan, 2011).

\section{The effect of CCTV on crime and fear}

One of the most seminal works was published by Brown (1996), who found mixed evidence of the effective use of CCTV on crime in three British cities. A well-known meta-analysis in this field was done by Welsh and Farrington (2009), who concluded that cameras are effective if systems are designed with close attention to the setting and its specific crime problems. They performed a meta-analysis of 41 studies to show that for car parks, CCTV has a reductive effect, but results are inconclusive for total crimes (Welsh \& Farrington, 2009). The reductive effect of CCTV was also confirmed by other studies elsewhere (Caplan, Kennedy, \& Petrossian, 2011; Ratcliffe et al., 2009; Tjoa \& Devon, 2010), while others show mixed results, such as those by Lett, Hier, and Walby (2010), Tjernberg and Granhag (2019), La Vigne et al. (2011), Ceccato (2013), Taylor, Koper, and Woods (2012), and no effect by Gerell (2016).

The most recent evidence is reported by Piza et al. (2019), which is a systematic review and meta-analysis of the effects of CCTV surveillance cameras on crime. The findings show that CCTV is associated with a significant and modest decrease in crime. The largest and most consistent effects of CCTV were observed in car parks. The results of the analysis also demonstrated evidence of significant crime reduction in other settings, particularly residential areas. CCTV schemes incorporating active monitoring generated larger effect sizes than did passive systems. Schemes deploying multiple interventions alongside CCTV generated larger effect sizes than did schemes deploying single or no 
other interventions alongside CCTV. As for the effect on safety perceptions, several studies show inconclusive findings of the effect of CCTV or that its effect was dependent on other security measures such as lighting (Cozens \& Davies, 2013; Fussey, 2013; Peek-Asa \& Casteel, 2010; Sanders \& Hannem, 2012; Skudder et al., 2018; Yavuz \& Welch, 2010).

Crime prevention based on modern technologies, such as cameras, alarms and lighting sensors, is often associated with large cities and rarely linked to rural areas (Weisheit and Donnermeyer, 2000). However, recent literature has shown signs of the expansion of technology as a preventive measure against property and wildlife crimes in rural areas (Aransiola \& Ceccato, 2020; Ceccato, 2016). This expansion trend was noticed early on by Sutton and Wilson (2004), who executed a descriptive analysis of data obtained through in-depth interviews on all 33 Australian CCTV schemes. The authors noted significant expansion of CCTV surveillance in smaller regional and rural centers and in suburban locations but were unclear about the effect in these environments. In a rural context, Mears, Scott, and Bhati (2007) made use of data from agricultural censuses, victimization surveys and interviews to test the effect of CCTV. They found CCTV to be associated with higher levels of victimization in rural areas in the United States. The direction of causality was a problem also mentioned in the study in rural Australia by Anderson and McCall (2005), that found that if perception of crime increases, CCTV usage also increases.

\section{CPTED, crime and fear}

The international literature is richly populated by examples of how one or a combination of multiple characteristics of houses, neighborhoods and street features come together to affect the geography of crime and perceived safety. Such studies accounted for more than half of the studies reviewed and belong to what is normally called "first generation CPTED" (Saville, 2013). Although most studies make use of CPTED principles to tackle crime and reduce fear, a share of them are of a different type. They are "before-after analyses" of a safety intervention. The maintenance and perception of an area are important for safety, but equally important is people's involvement in voluntary activities, from neighborhood cooperation to safety walking. The effectiveness of these activities is difficult to assess and varies; short-term evaluations dominate these studies.

Several examples of the literature show how specific and crime-tailored crime prevention interventions need to be in order to be effective. Positive results were found by Poyner (1991) after security improvements were made to parking lots, as well as by Tseng et al. (2004) in relation to the layout and management of garages; retail environments by Hunter and Jeffery (1997); parks by Knutsson (1997) and Iqbal and Ceccato (2015); streets by Armitage (2011); and schools by Bradshaw, Milam, Furr-Holden, and Lindstrom Johnson (2015) and Vagi et al. (2018).

Maintenance is a fundamental aspect of the safety of public places and an essential CPTED component assessed in many studies. Poorly maintained urban 
land affects people's perceptions of safety and also victimization (Branas et al., 2018). Poyner (1994) illustrated the effect of demolition in the United Kingdom showing that property crime decreased. In the United States, Freedman and Owens (2011) found that new construction and rehabilitation of existing housing led to reductions in violent crime but not in property offenses. In Chicago, Aliprantis and Hartley (2015) found significant reductions in homicide rates around demolition sites. Similar findings were reported by Kondo, Andreyeva, South, MacDonald, and Branas (2018) for violent crimes and alcohol availability, and by Branas et al. (2018) for overall crime and nuisances in neighborhoods below the poverty line.

Research also shows examples of urban design producing safer environments. Gray and Novacevski (2015) stated that architecture can encourage a more equitable use of the space and may diminish the sense of fear. Gray (2015) also showed how the built environment has an important role to play in addressing safety problems by presenting opportunities for local stakeholders. In addition, Vagi et al. (2018) assessed CPTED in school environments and showed that students' performance was generally associated with higher perceptions of safety and lower levels of violence perpetration and perceived risk.

\section{CPTED, crime and fear in transit environments}

Bus stops and transit stations are criminogenic places (Bowers, 2014; Cozens, Neale, Whitaker, \& Hillier, 2002, 2003; Cozens \& van der Linde, 2015; Loukaitou-Sideris, 1999, 2012, 2014; Loukaitou-Sideris \& Stieglitz, 2002; Newton, Johnson, \& Bowers, 2004; Uittenbogaard \& Ceccato, 2014). Previous research in transit environments has shown that design that promotes visibility and clear lines of sight, through the absence of nooks and corners, visible ticket booths, overpass (rather than underpass) walkways and separation of passenger flows promotes safety (Ceccato, Uittenbogaard, \&. Bamzar, 2013b; Gaylord \& Galliher, 1991; Loukaitou-Sideris, Liggett, \& Iseki, 2002; Myhre \& Rosso 1996). Similarly, Smith and Clarke (2000) pointed out that high crime rates in transit environments are due to overcrowding (high density, more potential offenders) and lack of supervision (low density, low levels of natural surveillance).

The weight of empirical evidence indicates that environmental factors include good lighting, good visibility, maintenance/cleanliness and presence of people. Surveillance through CCTV cameras has also been found to have some effect on crime reduction, but its effectiveness may differ by the type of offense, and the evidence is not always conclusive for transit environments (Armitage, 2006; Ceccato, Cats, \& Wang, 2015; Ceccato \& Newton, 2015; Newton, 2008; Squires, 1992; Uittenbogaard \& Ceccato, 2015; Welsh \& Farrington, 2009; Winge \& Knutsson, 2003).

Opportunities for crime are also dependent on stations' environmental attributes and type of neighborhood in which they are located (Ceccato et al., 2013b). This applies to city and country contexts (Ceccato, 2018). Venez 
Moudon et al. (2018) found that crime rates at transit stops are higher in densely populated neighborhoods because there are more potential offenders, whereas crime rates are lower when there are more people at transit stops because they offer higher levels of natural surveillance. In Brazil, Ceccato and Paz (2017) found that sexual violence was concentrated at the busiest central stations and at stations that also attract other types of violence and events of public disorder. These results lend general empirical support to situational mechanisms at work in transit environments and surrounding areas. Also in Brazil, De Souza and Miller (2012) indicated how situational factors help explain homicide within the favela.

Perceived safety in stations and bus stops also highlights the importance of CPTED. Cozens et al. (2003) utilized interactive virtual reality scenes as the environmental stimuli to elucidate where passengers' fears were located in and around the station and how service providers can make stations safer, in a representative sample of railway stations on a network in South Wales using CPTED. CCTV, more staff and maintenance are a few suggestions to improve perceived safety among passengers. The importance of CPTED is also highlighted elsewhere in the literature for both subway stations and for bus stops by Abenoza, Ceccato, Susilo, and Cats (2018); Ceccato, Uittenbogaard, and Bamzar (2013a). Other studies focused on smaller municipalities. Cozens and van der Linde (2015) assessed two different railway stations in Perth, Australia, to find that rail users perceived the station that was not designed using CPTED to be marginally safer than the one that exhibited CPTED qualities, partly because of the contexts of the stations.

\section{Unexpected outcomes and 'side effects' when planning for safe environments}

The international literature shows examples of interventions that are planned to deliberately make public places safe. Most of them succeed to different extents. Others fail-for various reasons and despite all "good intentions"-so producing unexpected outcomes (e.g., Jeong, Kang, \& Lee, 2017; Saleh, Saif, \& Sartawi, 2015; Shamsuddin \& Hussin, 2013). Although there might be many reasons why these interventions did not work as planned (e.g. lack of proper data, choice of study area, inadequate methods, organizational barriers), all these cases touched upon the importance of personnel training to obtain expected results (for further discussion, see for example Zahm, 2005).

This happens when, instead of improving safety, after intervention:

(a) more crime and/or fear are observed,

(b) crime decreased, but not for all types of crime,

(c) crime goes up and fear goes down,

(d) displacement of crime/fear in time or space were observed,

(e) safety is improved, but not for everybody, 
(f) unexpected consequences to the sustainability of the whole city occur, such as exclusion of users or geographical segregation of areas (e.g., gated communities).

(g) safety is improved but such an outcome is an unintended result of other factors or mechanisms not controlled for.

These types of unexpected results can be illustrated by the study by Cozens and van der Linde (2015) for rail stations and CPTED effectiveness, those discussed in White (1993) for commercial areas, or by England (2008) in selected neighborhoods in the United States. Similarly, promoting surveillance in an environment has been intended to create a safe place for customers, but it may also be perceived as an exclusionary practice to others who are non-customers (Akinci, 2015). These studies suggested that safety interventions have led unintentionally to social exclusion of certain groups of individuals.

Is there any risk (or "side effect") when prioritizing safety (using barriers) over other sustainability goals? One of the side effects of creating barriers is intensification of geographical segregation. There are studies that illustrate when safety (of some) has been prioritized to the detriment to other aspects of urban life, such as public transportation (for all). Gated communities are an example of a "desired safety solution" that in many countries has been legitimized by high crime rates and socioeconomic inequality (Branic \& Kubrin, 2018; Breetzke, Landman, \& Cohn, 2014; Carvalho, George, \& Anthony, 1997; Gliori, 2018; Grundström, 2018; Landman, 2004; Luymes, 1997). Inevitably, the outcome is that safety becomes a function of those who can afford it, a commodity objectified by the physical environment. In the South African context, Landman (2004) showed that gated communities have proliferated since 1994. Using as reference Johannesburg and Tshwane, Gauteng, the author suggested that these facilities cause a number of problems and raise serious concerns regarding social exclusion, citizenship and democracy. Her study calls for different planning approaches to different types of gated communities in order to begin to address some of the contemporary challenges that this type of housing/safety solution imposes to society as a whole.

Another side effect of gated communities is spatial fragmentation, namely "the break of continuity, contiguity and morphological coherence of urban" (Santos, 2020, p. 1). An example is illustrated by Gray (2015) who examined the fragmentation's impact caused by the insertion of two shopping malls in the neighboring area. The author suggested that the fragmentation of the urban fabric has led to serious implications in the social and spatial dynamics of the area, for social cohesion and sense of place.

A third side effect is mobility restrictions. Gated communities and barriers affect human mobility and ultimately human health and life chances (Bornioli, Parkhurst, \& Morgan, 2018; Branic \& Kubrin, 2018; Duncan et al., 2012; Tanulku, 2018). Research in a South African context by Landman (2012) shows examples of how these facilities mean longer distances to public transportation and limit access to public facilities for the rest of the population. The 


\section{Vania Ceccato}

so-called 'transit captives', particularly women, elderly and children might be the groups most affected by these disruptions (Ceccato, 2017).

Note that in the 12 articles about gated communities that were reviewed in this literature overview, 68 percent of studies showed that this housing form was associated with lower crime rates or fear (often inside the compounds/facilities), 8 percent showed a negative effect (crime increase or fear increase), 15 percent showed no effect, and 9 percent were inconclusive. The effect of securitization of the urban environment seems to be more evident in studies of perceived safety than for victimization, especially because it is not easy to compare total crimes inside and/or outside these facilities (Rogers, 2005, 2007). Yet, in a recent study by Hedayati-Marzbali, Tilaki, and Abdullah (2017) residents in gated communities, despite experiencing relatively high levels of social cohesion, showed moderate safety levels when compared with those living outside.

\subsection{Concluding remarks}

The expected positive effect of lighting, CCTV and other CPTED features on reducing crime and maximizing safety perceptions is confirmed by the literature reported in this chapter, despite great variations in methods used in these studies. This conclusion derives from the overall assumption that there is a great deal of international research that shows significant links between the urban environment and safety, mainly from North America and Western Europe. Turning back to the initial question, what makes a public place safe?

Lighting and maintenance are for sure important components of a safe public place but these characteristics often do not come alone. In the studies reported in this review, lighting is often a "surrogate" (or interacts) with other aspects of the environment that lead to reduced crime risk, such as good visibility. Studies show that lighting has a reductive effect on a variety of types of crime, from public disorder to homicides, and on fear of crime. However, the "fishbowl effect" is also mentioned in a number of studies dealing with fear of crime.

Security cameras have an overarching effect of reducing crime but for safety perceptions; such an effect depends on the type of user. In addition, its effectiveness seems to be related to other investments, such as in lighting and other security measures. In recent decades, CCTV together with other modern technologies have become more widespread in rural areas as crime prevention tools. Research indicates that CCTV can become more effective if security systems are designed with great responsiveness to the urban design and its specific crime problems.

Among those classified as CPTED studies, maintenance is a fundamental aspect of the safety of public places, for a variety of environments, from school grounds and parking lots, to transit stations. Findings also show that, together with other interventions, people's involvement in voluntary activities (e.g., safety walks, neighborhood watch) may reduce crime and/or improve safety perceptions. 
Studies show that there are risks of "side effects" when safety interventions do not take into account the city's overall sustainability-more research is therefore needed in this topic. Better processes and methods are needed to tackle safety problems other than reducing permeability and maximizing control by creating barriers (gates, fences, walls). Planning decisions must be made with regard to questions beyond the technical debate of whether or not a particular solution 'works' against crime or fear. Gated communities may be an effective technical solution but it is not, we state, a sustainable one. If a city has to be called sustainable, safety and mobility have to be rights attained by all. Therefore, future research should assess potential areas of conflict between these sustainability goals.

A note of caution is necessary, because this literature overview is based on studies with different types of methods and a variety of approaches. In addition, although our sample of articles covers more than 4,000 articles, it is biased towards expected positive results (it is impossible to know how many studies that have produced negative or "unexpected" results were never published). The impact of this positive biases towards evidence-based planning should be further investigated in future studies.

In addition, "good outcomes" (e.g., illumination reduces fear of crime) are more likely to get published. However, it is argued here that "bad outcomes" (e.g., illumination increases fear of crime) are just as valuable as those that show that the intervention has "succeeded". Although there might be many reasons why interventions did not work as planned, lack of proper training has been highlighted as a common cause in many studies. Sometimes the intervention is evaluated too early in the process; in others, too late. Or it can be that the method used in evaluation is not appropriate. Sometimes the context and scale of a particular problem/case play a role in affecting outcomes. It is no surprise when an intervention that worked in big cities does not produce the same results in a rural community. There are lessons to be learned for future actions about "faulty processes" and "bad outcomes": What can be done differently to avoid these pitfalls in the future?

\section{Note}

1 The chapter summarizes and builds on parts of the report written in Swedish by Ceccato et al. (2019), commissioned by the Swedish National Board of Housing, Building and Planning (Boverket), that had as its main aim to inspect current national and international theories and practices in situational crime prevention and safety ensuring measures. The author would like to thank Lisandra Vasquez and Ana Canabarro for executing the data collection reported in Ceccato et al. (2019). 


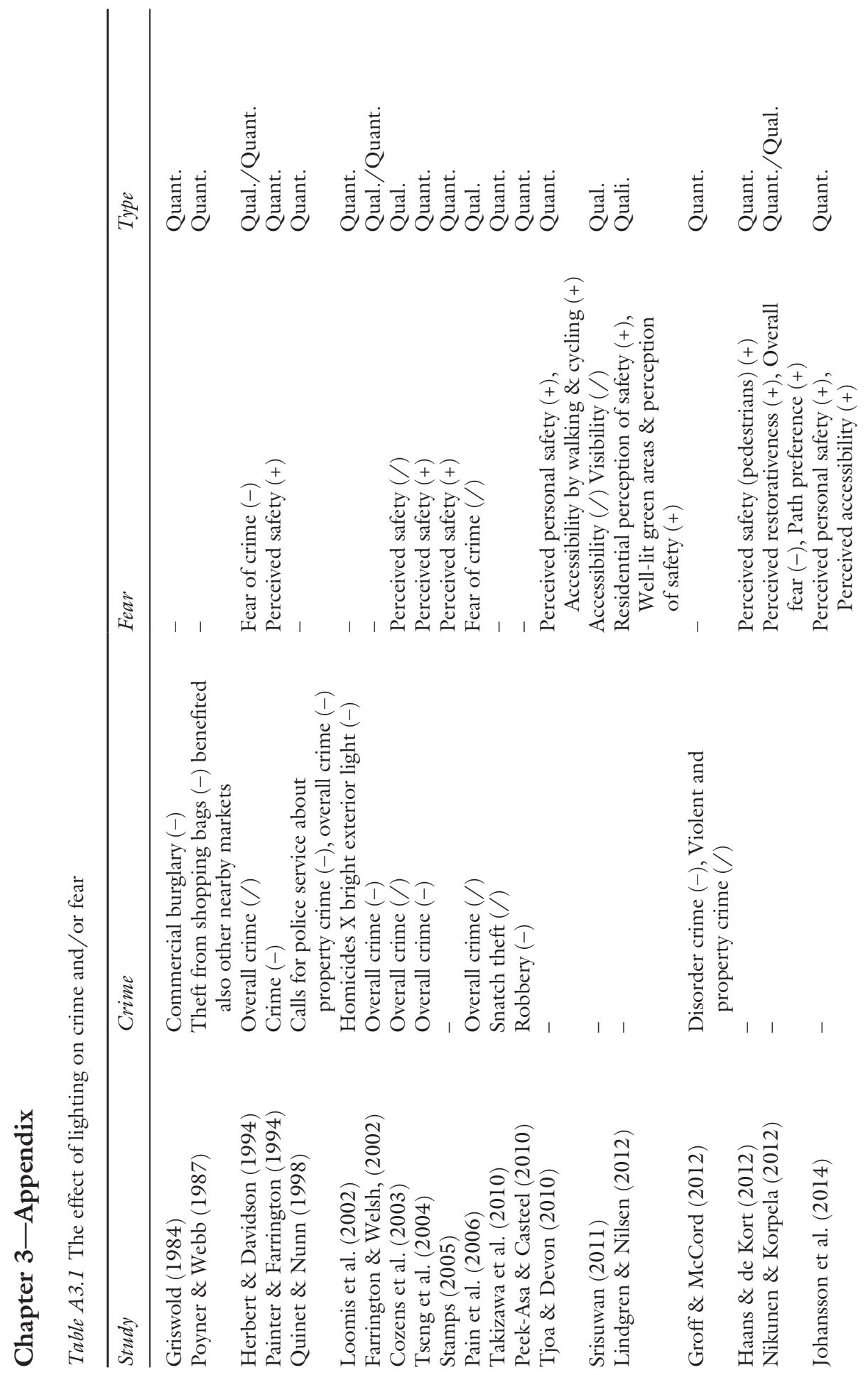



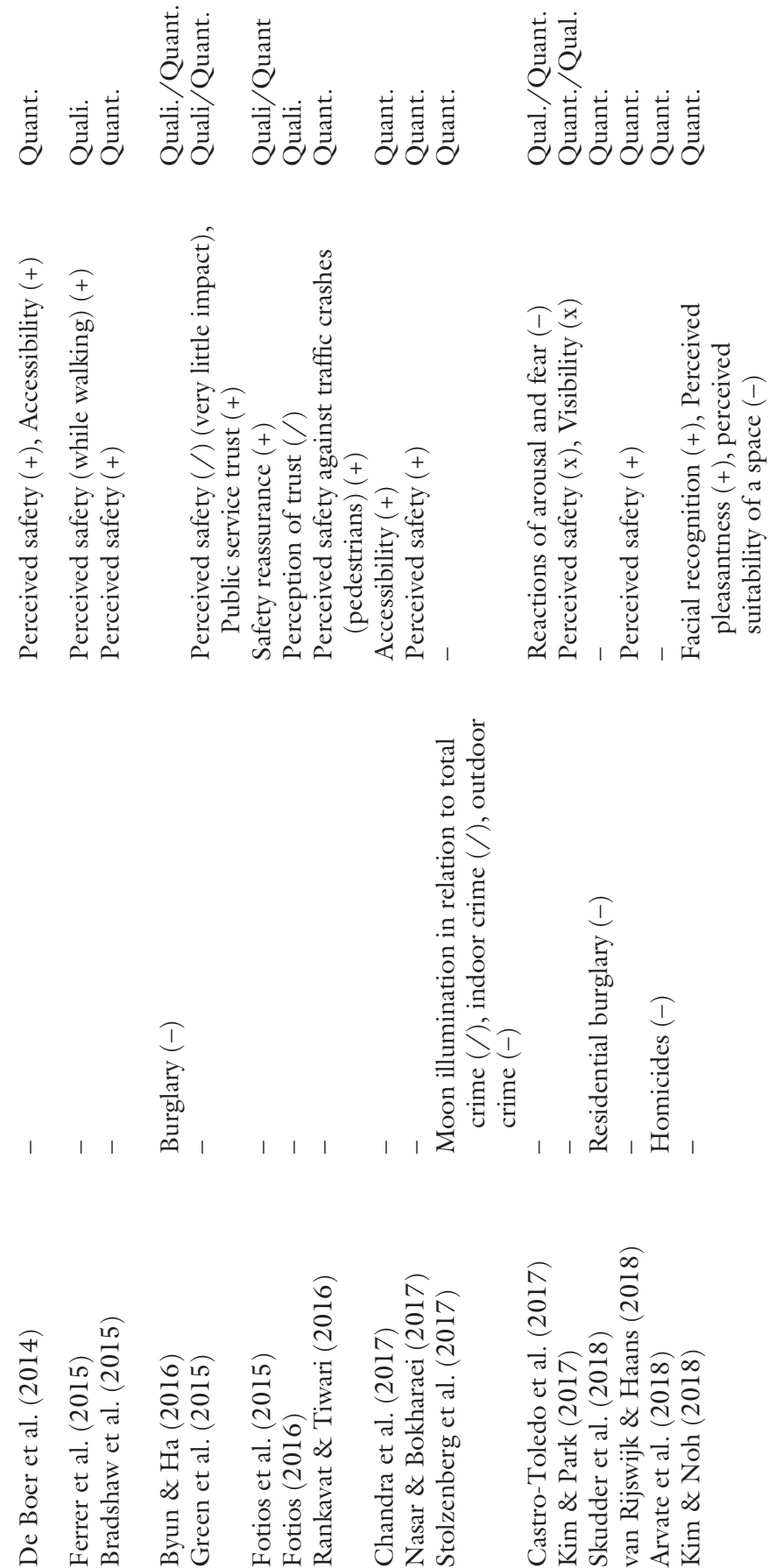


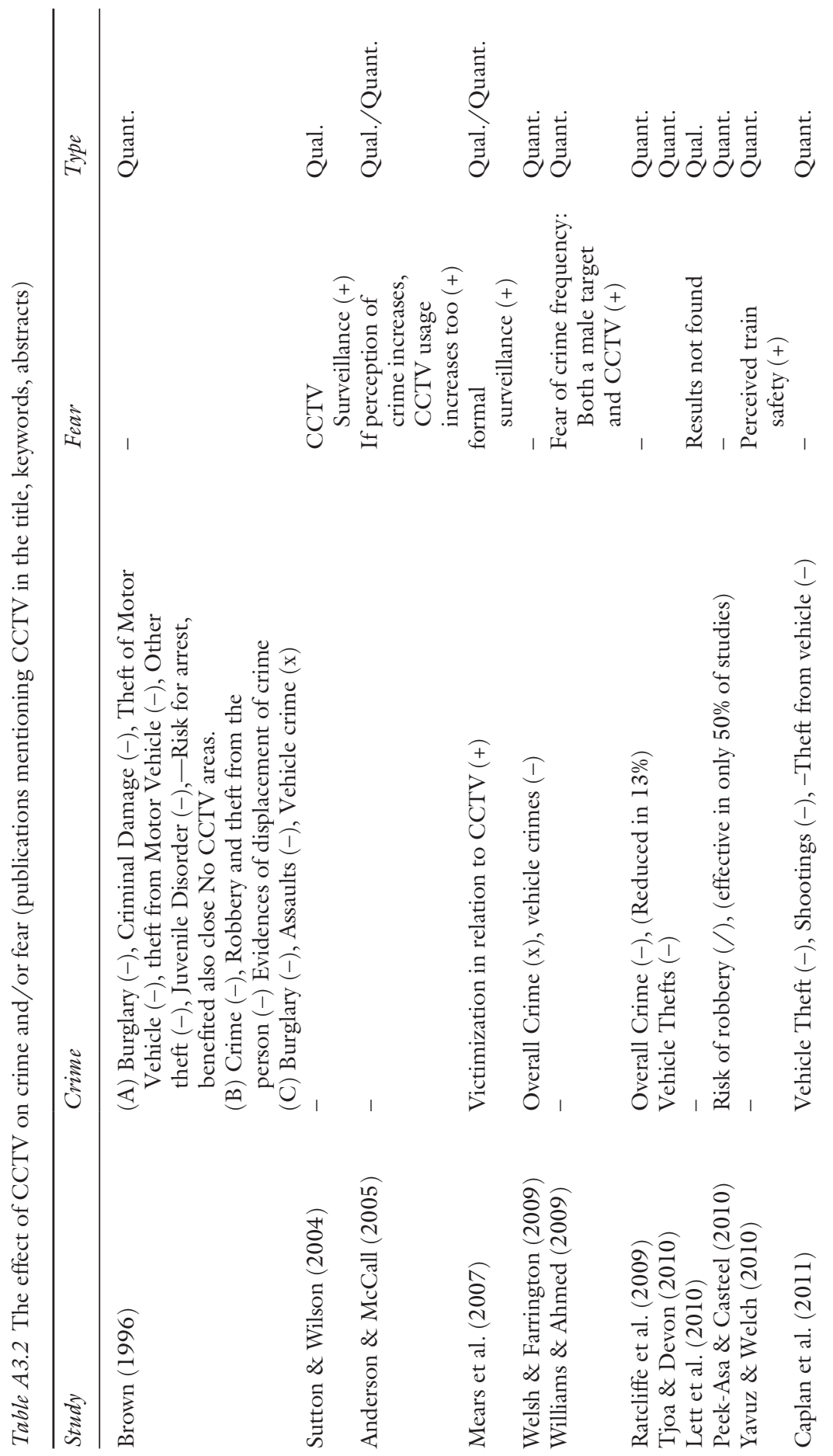


$\frac{\dot{\Xi}}{\stackrel{\Xi}{\Xi}}$

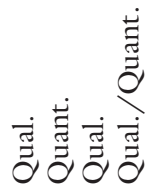

离

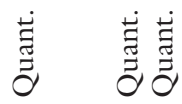

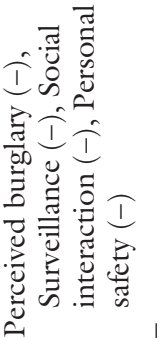

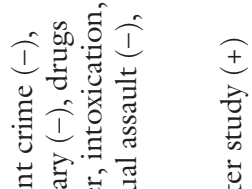

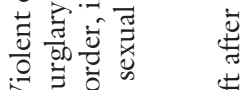

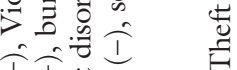

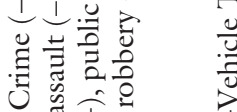

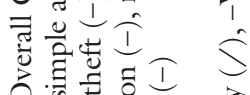

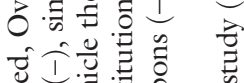

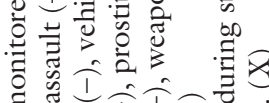

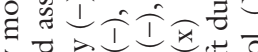
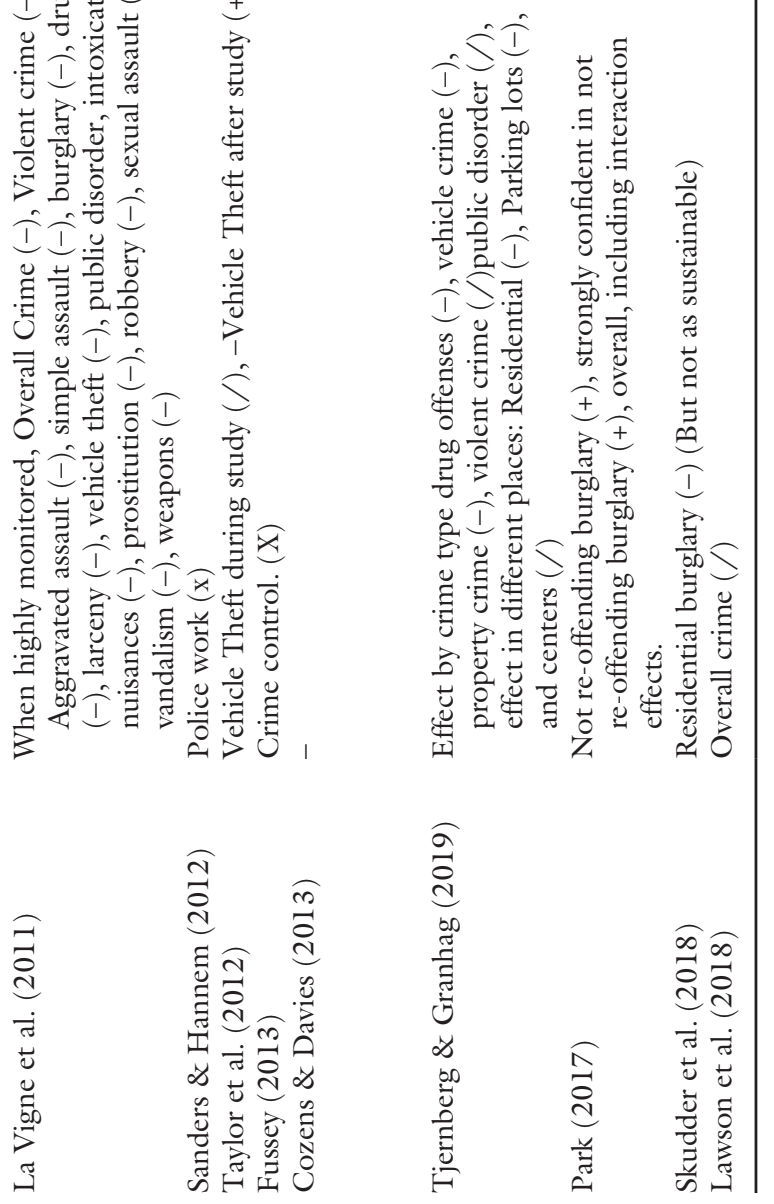


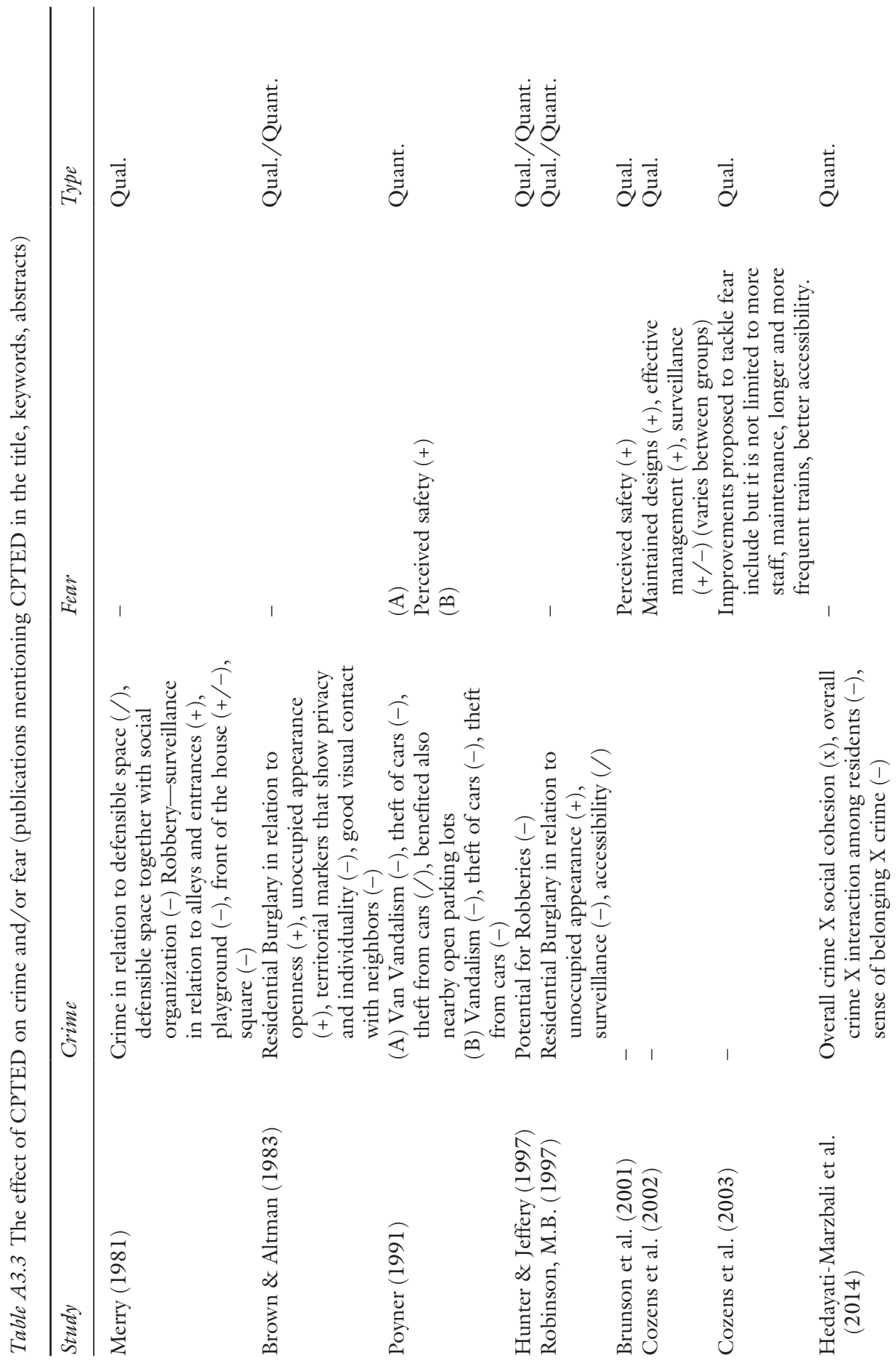


言言言

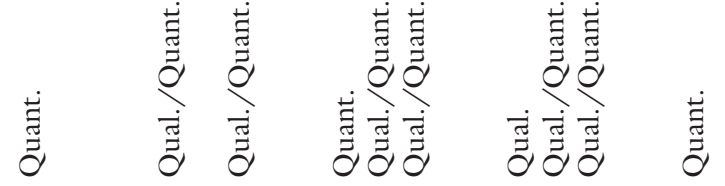

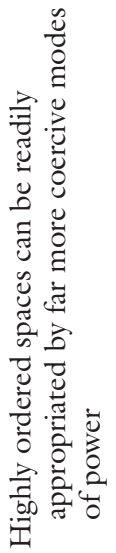
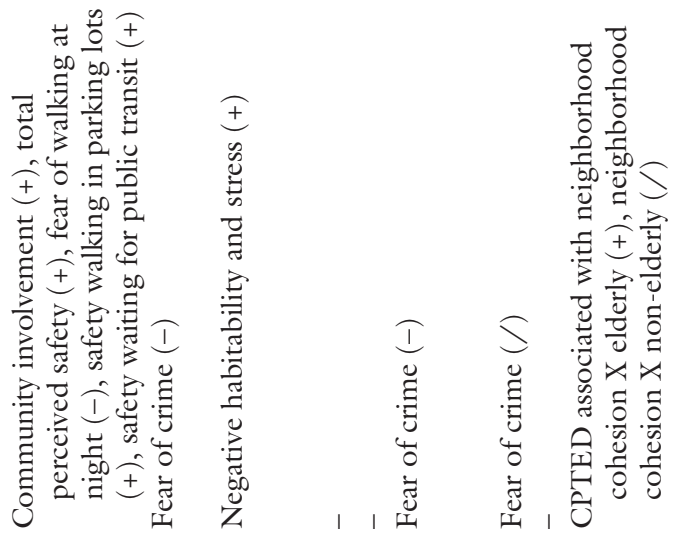

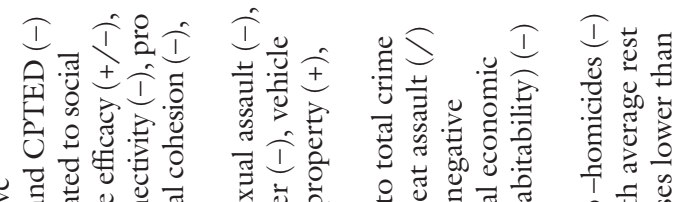

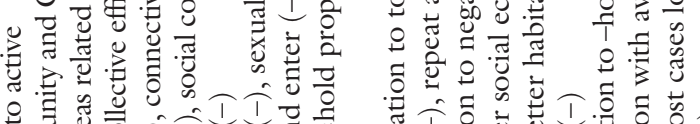

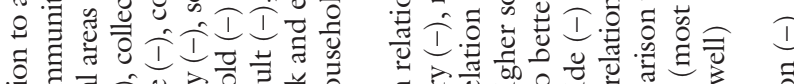

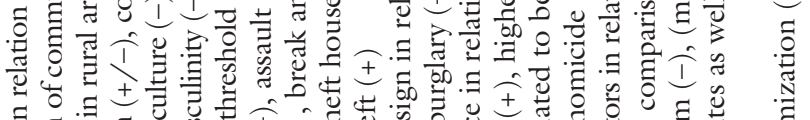
ヨ.

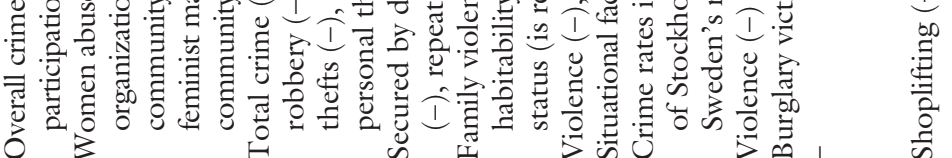
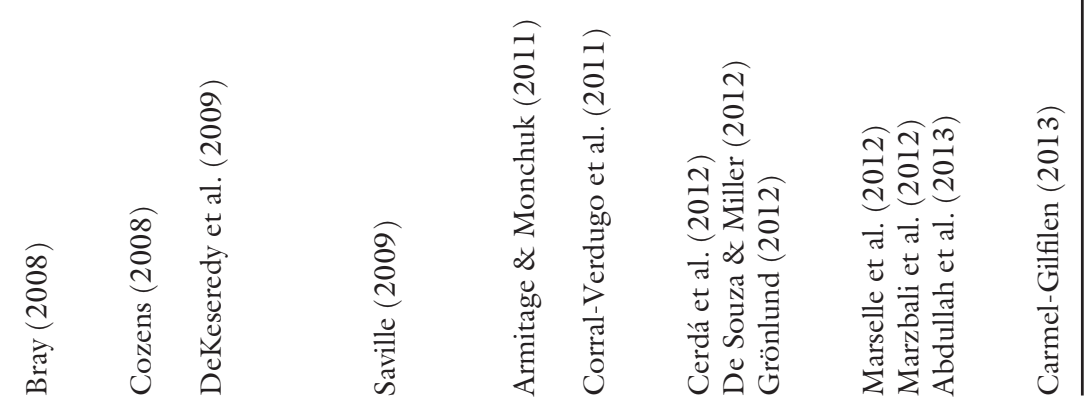


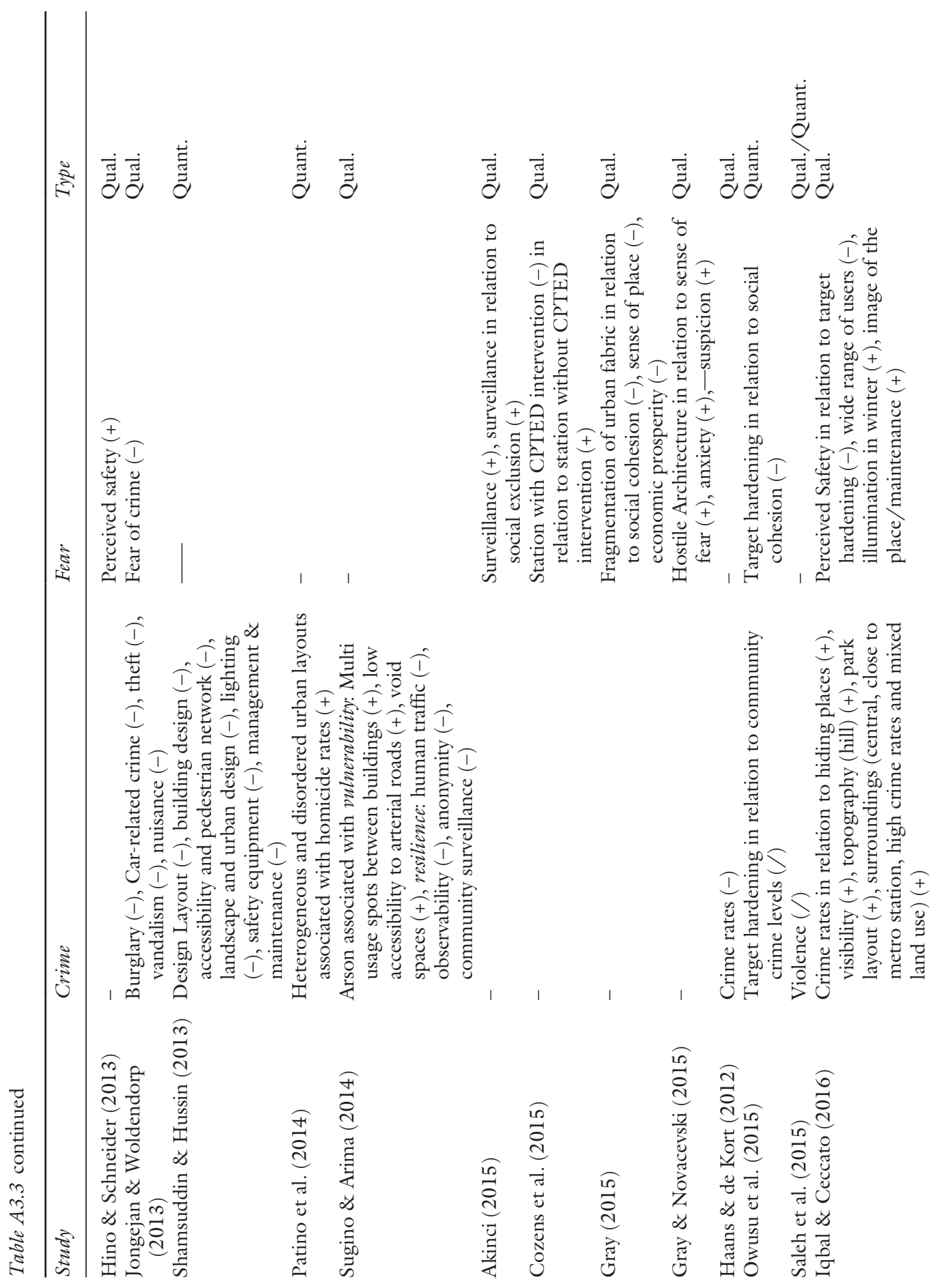


离

茪 节

节

๘̊
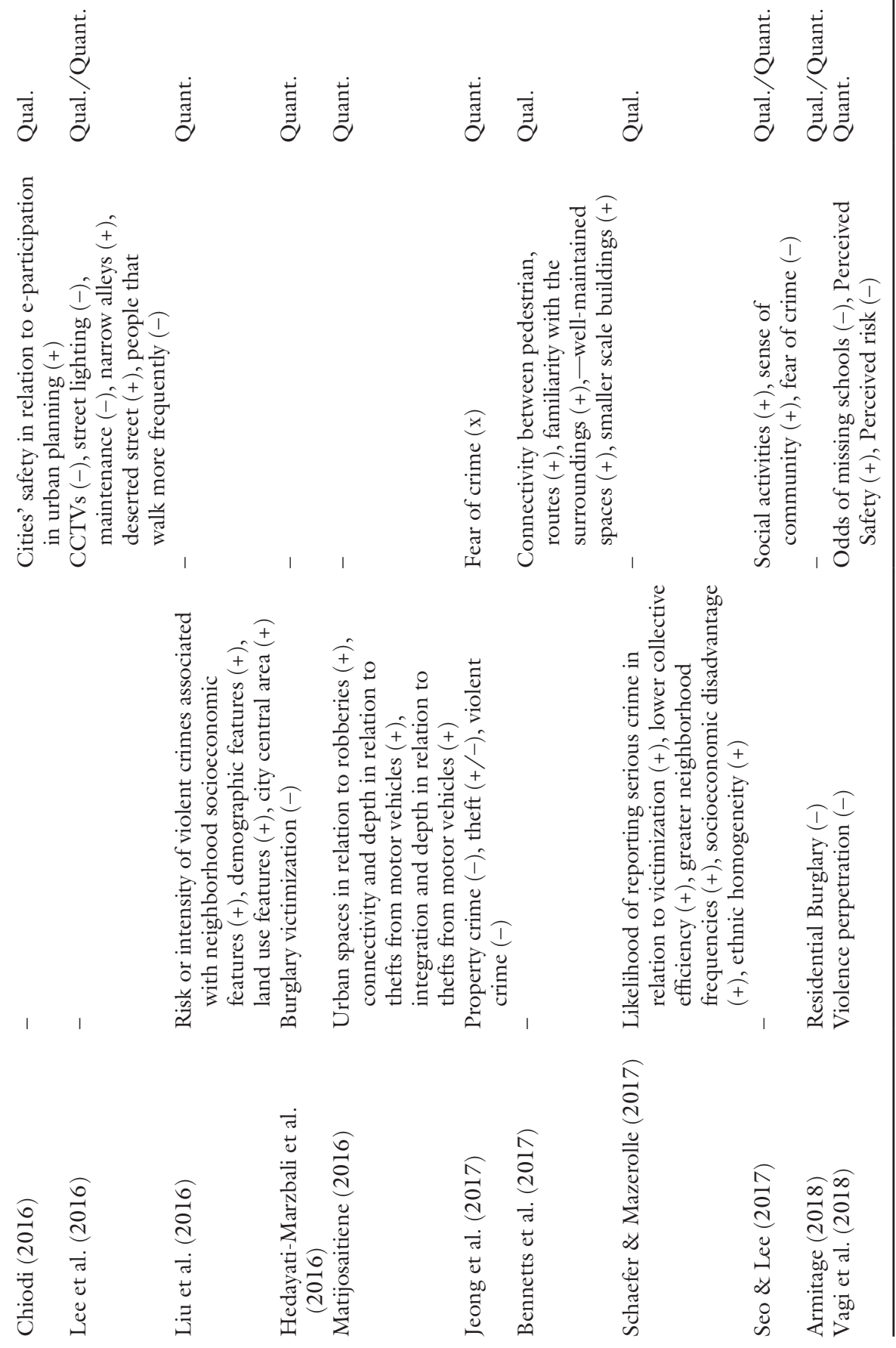


\section{Vania Ceccato}

\section{References}

Abenoza, R. F., Ceccato, V., Susilo, Y. O., \& Cats, O. (2018). Individual, travel, and bus stop characteristics influencing travelers' safety perceptions. Transportation Research Record, 2672, 19-28.

Abdullah, A., Marzbali, M. H., \& Tilaki, M. J. M. (2013). Predicting the influence of CPTED on perceived neighbourhood cohesion: Considering differences across age. Journal of Environmental Psychology, 36, 54-64.

Akinci, G. M. (2015). The purposes and meanings of surveillance: A case study in a shopping mall in Ankara, Turkey. Security Journal, 28, 39-53.

Aliprantis, D., \& Hartley, D. (2015). Blowing it up and knocking it down: The local and city-wide effects of demolishing high concentration public housing on crime. Journal of Urban Economics, 88, 67-81.

Anderson, K. M., \& McCall, M. (2005). Farm Crime in Australia. Canberra: Australian Institute of Criminology.

Aransiola, T. J. and Ceccato, V. (2020). The role of modern technology in rural situational crime prevention: a review of the literature. In A. Harkness (Ed.), Rural Crime Prevention - Theory, Tactics and Techniques (pp. 58-72). Oxford: Routledge.

Armitage, R. (2006). Predicting and preventing: Developing a risk assessment mechanism for residential housing. Crime Prevention and Community Safety, 8, 137-149.

Armitage, R. (2011). The Impact of Connectivity and Through-Movement within Residential Developments on Levels of Crime and Anti-Social Behaviour. (Unpublished Dissertation), University of Huddersfield, UK.

Armitage, R. (2018). Burglars' take on Crime Prevention Through Environmental Design (CPTED): Reconsidering the relevance from an offender perspective. Security Journal, 31, 285-304.

Armitage, R., \& Monchuk, L. (2011). Sustaining the crime reduction impact of designing out crime: re-evaluating the Secured by Design scheme 10 years on. Security Journal, 24(4), 320-343.

Arvate, P., Falsete, F. O., Ribeiro, F. G., \& Souza, A. P. (2018). Lighting and homicides: Evaluating the effect of an electrification policy in rural Brazil on violent crime reduction. Journal of Quantitative Criminology, 34, 1047-1078.

Atkins, S., Husain, S., \& Storey, A. (1991). The influence of street lighting on crime and fear of crime. Retrieved from London: www.celfosc.org/biblio/seguridad/atkins.pdf (accessed 15 January 2020).

Bennetts, H., Soebarto, V., Oakley, S., \& Babie, P. (2017). Feeling safe and comfortable in the urban environment. Journal of Urbanism, 10, 401-421.

Bornioli, A., Parkhurst, G., \& Morgan, P. L. (2018). The psychological wellbeing benefits of place engagement during walking in urban environments: A qualitative photoelicitation study. Health o Place, 53, 228-236.

Bowers, K. (2014). Risky facilities: Crime radiators or crime absorbers? A comparison of internal and external levels of theft. Journal of Quantitative Criminology, 30, 389-414.

Box, S., Hale, C., \& Andrews, G. (1988). Explaining fear of crime. The British Journal of Criminology, 28(3), 340-356.

Bradshaw, C. P., Milam, A. J., Furr-Holden, C. D. M., \& Lindstrom Johnson, S. (2015). The School Assessment for Environmental Typology (SAfETy): An observational measure of the school environment. American Journal of Community Psychology, 56, 280-292.

Branas, C. C., South, E., Kondo, M. C., Hohl, B. C., Bourgois, P., Wiebe, D. J., \& MacDonald, J. M. (2018). Citywide cluster randomized trial to restore blighted vacant land and its effects on violence, crime, and fear. Proceedings of the National Academy of Sciences, 115, 2946. 
Branic, N., \& Kubrin, C. E. (2018). Gated communities and crime in the United States. In G. Bruinsma \& S. D. Johnson (Eds.), The Oxford Handbook of Environmental Criminology (Vol. 1). New York: Oxford University Press.

Bray, D. (2008). Designing to govern: Space and power in two Wuhan communities. Built Environment (1978-), 34, 392-407.

Breetzke, G. D., Landman, K., \& Cohn, E. G. (2014). Is it safer behind the gates? Crime and gated communities in South Africa. Journal of Housing and the Built Environment, $29,123-139$.

Brown, B. B., \& Altman, I. (1983). Territoriality, defensible space and residential burglary: An environmental analysis. Journal of Environmental Psychology, 3, 203-220.

Brown, B. (1996). CCTV in three town centers in England. In R. V. Clarke (Ed.), Situational Crime Prevention—Successful Case Studies (pp. 167-182). USA: Lynne Rienner Publishers.

Brunson, L., Kuo, F. E., \& Sullivan, W. C. (2001). Resident appropriation of defensible space in public housing: Implications for safety and community. Environment and Behavior, 33, 626-652.

Byun, G., \& Ha, M. (2016). Factors of a surveillance environment that affect burglaries in commercial districts. Journal of Asian Architecture and Building Engineering, 15, 73-80.

Caplan, J. M., Kennedy, L. W., \& Petrossian, G. (2011). Police-monitored CCTV cameras in Newark, NJ: A quasi-experimental test of crime deterrence. Journal of Experimental Criminology, 7, 255-274.

Carmel-Gilfilen, C. (2013). Bridging security and good design: Understanding perceptions of expert and novice shoplifters. Security Journal, 26, 80-105.

Carvalho, M., George, R. V., \& Anthony, K. H. (1997). Residential satisfaction in Condomínios exclusivos (gate-guarded neighborhoods) in Brazil. Environment and Behavior, 29, 734-768.

Castro-Toledo, F., Perea-Garcia, J., Bautista-Ortuno, R., \& Mitkidis, P. (2017). Influence of environmental variables on fear of crime: Comparing self-report data with physiological measures in an experimental design. Journal of Experimental Criminology, 13, 537-545.

Ceccato, V. (2013). Moving Safely: Crime and Perceived Safety in Stockholm's Subway Stations. Plymouth: Lexington.

Ceccato, V. (2016). Rural Crime and Community Safety. New York: Routledge.

Ceccato, V. (2017). Women's victimisation and safety in transit environments. Crime Prevention and Community Safety, 19, 163-167.

Ceccato, V. (2018). Crime in transit environments: Lessons from Stockholm (Sweden) and São Paulo (Brazil) metro systems: 交通环境犯罪: 从瑞典斯德哥尔摩和巴西圣保罗 地铁系统的经验总结. Landscape Architecture, 7 .

Ceccato, V., Cats, O., \& Wang, Q. (2015). The geography of pickpocketing at bus stops: An analysis of grid cells. In V. Ceccato \& A. Newton (Eds.), Safety and Security in Transit Environments: An Interdisciplinary Approach (pp. 76-98). London: Palgrave Macmillan UK.

Ceccato, V., \& Lukyte, N. (2011). Safety and sustainability in a city in transition: The case of Vilnius, Lithuania. Cities, 28, 83-94.

Ceccato, V., \& Newton, A. (Eds.). (2015). Safety and Security in Transit Environments: An Interdisciplinary Approach. London: Palgrave.

Ceccato, V., \& Paz, Y. (2017). Crime in São Paulo's metro system: Sexual crimes against women. Crime Prevention and Community Safety, 19, 211-226.

Ceccato, V., Uittenbogaard, A., \& Bamzar, R. (2013a). Security in Stockholm's underground stations: The importance of environmental attributes and context. Security Journal, 26, 33-59. 


\section{Vania Ceccato}

Ceccato, V., Uittenbogaard, A. C., \& Bamzar, R. (2013b). Safety in Stockholm's underground stations: The importance of environmental attributes and context. Security Journal, 26, 33-59.

Ceccato, V., Vasquez, L., Langefors, L., Canabarro, A., \& Petersson, R. (2019). En trygg stadsmiljö: Teori och praktik för brottsförebyggande \& trygghetsskapande åtgärder. Retrieved from Stockholm: http://kth.diva-portal.org/smash/get/diva2:1358155/ FULLTEXT01.pdf (accessed 12 November 2019).

Cerdá, M., Morenoff, J. D., Hansen, B. B., Tessari Hicks, K. J., Duque, L. F., Restrepo, A., \& Diez-Roux, A. V. (2012). Reducing violence by transforming neighborhoods: A natural experiment in Medellín, Colombia. American Journal of Epidemiology, 175, 1045-1053.

Chandra, S., Jimenez, J., \& Radhakrishnan, R. (2017). Accessibility evaluations for nighttime walking and bicycling for low-income shift workers. Journal of Transport Geography, 64, 97-108.

Chiodi, S. I. (2016). Crime prevention through urban design and planning in the smart city era: The challenge of disseminating CP-UDP in Italy: learning from Europe. Journal of Place Management and Development, 9, 137-152.

Clarke, R. V. (2012). The Theory of Crime Prevention through Environmental DesignCPTED. https://pdfs.semanticscholar.org/4a94/e72074e829aba49ff001el77870d37bel3d5.pdf (accessed 20 February 2020).

Cohen, L. E., \& Felson, M. (1979). Social change and crime rate trends: A routine activity approach. American Sociological Review, 44, 588-608.

Corral-Verdugo, V., M. Frías-Armenta, \& González-Lomelí, D. (2011). Environmental factors in housing habitability as determinants of family violence. In Bio-Psycho-Social Perspectives on Interpersonal Violence (pp. 125-142). New York: Nova Science Publishers, Inc

Cozens, P. (2008) Crime prevention through environmental design in Western Australia: planning for sustainable urban futures. International Journal of Sustainable Development and Planning, 3, 272-292.

Cozens, P., \& Davies, T. (2013). Crime and residential security shutters in an Australian suburb: Exploring perceptions of 'Eyes on the Street', social interaction and personal safety. Crime Prevention and Community Safety, 15, 175-191.

Cozens, P., \& Love, T. (2015). A review and current status of Crime Prevention through Environmental Design (CPTED). Journal of Planning Literature, 30, 393-412.

Cozens, P., Neale, R., Whitaker, J., \& Hillier, D. (2002). Managing crime and the fear of crime at railway stations-A case study in South Wales (UK). International Journal of Transport Management, 1, 121-132.

Cozens, P., Neale, R., Whitaker, J., \& Hillier, D. (2003). Investigating personal safety at railway stations using "virtual reality" technology. Facilities, 21, 188-194.

Cozens, P. M., Neale, R. H., Whitaker, J., Hillier, D., \& Graham, M. (2003). A critical review of street lighting, crime and fear of crime in the British city. Crime Prevention and Community Safety, 5, 7-24.

Cozens, P. M., Saville, G., \& Hillier, D. (2005). Crime prevention through environmental design (CPTED): A review and modern bibliography. Property Management, $23,328-356$.

Cozens, P., \& van der Linde, T. (2015). Perceptions of Crime Prevention Through Environmental Design (CPTED) at Australian railway stations. Journal of Public Transportation, 18, 73-92.

Crowe, T. (2000). Crime Prevention Through Environmental Design: Applications of Architectural Design and Space Management Concepts. Oxford: Butterworth-Heinemann. 
De Boer, J., Heylen, D. K. J., \& Teeuw, W. B. (2014). Persuasive ways to change entrance use of buildings. Psychology Journal, 12, 71-86.

De Souza, E., \& Miller, J. (2012). Homicide in the Brazilian favela: Does opportunity make the killer? British Journal of Criminology, 52, 786-807.

DeKeseredy, W. S., Donnermeyer, J. F., \& Schwartz, M. D. (2009). Toward a gendered Second Generation CPTED for preventing woman abuse in rural communities. Security Journal, 22, 178-189.

Duncan, D. T., Castro, M. C., Gortmaker, S. L., Aldstadt, J., Melly, S. J., \& Bennett, G. G. (2012). Racial differences in the built environment-body mass index relationship? A geospatial analysis of adolescents in urban neighborhoods. International Journal of Health Geographics, 11.

Eck, J. E. (2019). Place Managers and Crime Places. Oxford: Oxford University Press.

England, M. (2008). When 'good neighbors' go bad: Territorial geographies of neighborhood associations. Environment and Planning A, 40, 2879-2894.

Farrington, D. P., \& Welsh, B. C. (2002). Improved street lighting and crime prevention. Justice Quarterly, 19, 313-342.

Felson, M. (2002). Crime and Everyday Life. Thousand Oaks: Sage.

Ferraro, K. F. (1995). Fear of Crime: Interpreting Victimization Risk. Albany, NY: State University of New York Press.

Ferraro, K. F. (1996). Women's fear of victimization: Shadow of sexual assault? Social Forces, 75, 667-690.

Ferrer, S., Ruiz, T., \& Mars, L. (2015). A qualitative study on the role of the built environment for short walking trips. Transportation Research Part F-Traffic Psychology and Behaviour, 33, 141-160.

Fotios, S. (2016). Comment on empirical evidence for the design of public lighting. Safety Science, 86, 88-91.

Fotios, S., Unwin, J., \& Farrall, S. (2015). Road lighting and pedestrian reassurance after dark: A review. Lighting Research \& Technology, 47, 449-469.

Freedman, M., \& Owens, E. G. (2011). Low-income housing development and crime. Journal of Urban Economics, 70, 115-131.

Fussey, P. (2013). Contested topologies of UK counterterrorist surveillance: The rise and fall of Project Champion. Critical Studies on Terrorism, 6, 351-370.

Garofalo, J., \& Laub, J. (1978). The fear of crime: broadening our perspective. Victimology, 3(3-4), 242-253.

Gaylord, M. S., \& Galliher, J. F. (1991). Riding the underground dragon: Crime control and public order on Hong Kong's mass transit railway. British Journal of Criminology, $31,15-26$.

Gerell, M. (2016). Hot spot policing with actively monitored CCTV cameras: Does it reduce assaults in public places? International Criminal Justice Review, 26, 187-201.

Gliori, G. (2018). Grindsamhällen: Är det något att utveckla inom den svenska stadsplaneringen? (Independent thesis Basic level (degree of Bachelor) Student thesis).

Gray, E., Jackson, J., \& Farrall, S. (2008). Reassessing the fear of crime. European Journal of Criminology, 5, 363-380.

Gray, E., Jackson, J., \& Farrall, S. (2011). Feelings and functions in the fear of crime: Applying a new approach to victimisation insecurity. British Journal of Criminology, $51,75-94$.

Gray, F. (2015). The misanthropes, larrikins and mallrats of Market Square: An enduring public space dilemma in Central Geelong. In SAHANZ 2015: Architecture Institutes and Change. Proceedings of the 32nd Annual Conference of Society of Architectural Historians Australia and New Zealand, Society of Architectural Historians Australia and New Zealand, Sydney, NSW, pp. 218-230. 
Gray, F., \& Novacevski, M. (2015). Unlawful acts, unkind architecture and unhelpful perceptions: A case study of Market Square Mall, Geelong. In Proceedings of the Safe Cities Conference 2015, Association for Sustainability in Business, Nerang, Qld., pp. 4-18.

Green, J., Perkins, C., Steinbach, R., \& Edwards, P. (2015). Reduced street lighting at night and health: A rapid appraisal of public views in England and Wales. Health and Place, 34, 171-180.

Griswold, D. B. (1984). Crime prevention and commercial Burglary: A time series analysis. Journal of Criminal Justice, 12, 493-501.

Groff, E., \& McCord, E. S. (2012). The role of neighborhood parks as crime generators. Security Journal, 25, 1-24.

Grundström, K. (2018). Grindsamhälle: the rise of urban gating and gated housing in Sweden. Housing Studies, 33, 18-39.

Grönlund, B. (2012). Is hammarby sjöstad a model case? Crime prevention through environmental design in Stockholm, Sweden. In The Urban Fabric of Crime and Fear (pp. 283-310). Dordrecht: Springer Netherlands.

Haans, A., \& de Kort, Y. A. W. (2012). Light distribution in dynamic street lighting: Two experimental studies on its effects on perceived safety, prospect, concealment, and escape. Journal of Environmental Psychology, 32, 342-352.

Hedayati-Marzbali, M., A. Abdullah, N. A. Razak \& Maghsoodi Tilaki, M. J. (2014). Examining social cohesion and victimization in a Malaysian multiethnic neighborhood. International Journal of Law, Crime and Justice, 42, 384-405.

Hedayati-Marzbali, M. H., Esmaieli, M., Abolghasemi, H., \& Marzbali, M. H. (2016). Tetracycline adsorption by $\mathrm{H} 3 \mathrm{PO} 4$-activated carbon produced from apricot nut shells: A batch study. Process Safety and Environmental Protection, 102, 700-709.

Hedayati-Marzbali, M., Tilaki, M. J. M., \& Abdullah, A. (2017). Assessing the effect of neighbourhood structure on residents' perceptions of safety in gated communities: A case study of Iran. Safer Communities, 16, 3-19.

Herbert, D., \& Davidson, N. (1994). Modifying the built environment, the impact of improved lighting. Geoforum, 25, 339-350.

Higgins, J. P., \& Green, S. (Eds.). (2011). Cochrane Handbook for Systematic Reviews of Interventions (Vol. 4). Chichester, UK: John Wiley \& Sons.

Hino, K., \& Schneider R. H. (2013). Planning for crime prevention in Japan. Built Environment, 39(1), 114-139.

Hunter, R. D., \& Jeffery, R. (1997). Preventing convenience store robbery through environmental design. In R. V. Clarke (Ed.), Situational Crime Prevention-Successful Case Studies (pp. 191-199). USA: Lynne Rienner Publishers.

Iqbal, A., \& Ceccato, V. (2015). Is CPTED useful to guide the inventory of safety in parks? A study case in Stockholm, Sweden. International Criminal Justice Review, 26, 150-168.

Jackson, J., \& Gray, E. (2010). Functional fear and public insecurities about crime. British Journal of Criminology, 50, 1-22.

Jeong, Y., Kang, Y., \& Lee, M. (2017). Effectiveness of a project applying crime prevention through environmental design in an urban area in South Korea. Journal of Asian Architecture and Building Engineering, 16, 543-549.

Johansson, M., Pedersen, E., Maleetipwan-Mattsson, P., Kuhn, L., \& Laike, T. (2014). Perceived outdoor lighting quality (POLQ): A lighting assessment tool. Journal of Environmental Psychology, 39, 14-21.

Johansson, M., Rosen, M., \& Kuller, R. (2011). Individual factors influencing the assessment of the outdoor lighting of an urban footpath. Lighting Research \& Technology, $43,31-43$.

Jongejan, A., \& Woldendorp, T. (2013). A successful CPTED approach: The Dutch 'police label secure housing'. Built Environment (1978-), 39, 31-48. 
Kim, D., \& Park, S. (2017). Improving community street lighting using CPTED: A case study of three communities in Korea. Sustainable Cities and Society, 28, 233-241.

Kim, D. H., \& Noh, K. B. (2018). Perceived adequacy of illumination and pedestrians' night-time experiences in urban obscured spaces: A case of London. Indoor and Built Environment, 27, 1134-148.

Knutsson, J. (1997). Restoring public order in a city park. Policing for prevention: Reducing crime. National Council for Crime Prevention. Stockholm: BRÅ.

Kondo, M. C., Andreyeva, E., South, E. C., MacDonald, J. M., \& Branas, C. C. (2018). Neighborhood interventions to reduce violence. Annual Review of Public Health, $39,253-271$.

Koskela, H. (2002). Video surveillance, gender, and the safety of public urban space: "Peeping tom" goes high tech? Urban Geography, 23, 257-278.

LaGrange, R. L., Ferraro, K. F., \& Supancic, M. (1992). Perceived risk and fear of crime: Role of social and physical incivilities. Journal of Research in Crime and Delinquency, 29, 311-334.

Landman, K. (2004). Gated communities in South Africa: The challenge for spatial planning and land use management. The Town Planning Review, 75, 151-172.

Landman, K. (2012). Reconsidering crime and urban fortification in South Africa. In V. Ceccato (Ed.), The Urban Fabric of Crime and Fear (pp. 239-264). Dordrecht: Springer Netherlands.

La Vigne, N. G. L., Lowry, S. S., Markman, J. A., \& Dwyer, A. M. (2011). Evaluating the Use of Public Surveillance Cameras for Crime Control and Prevention. Washington, DC: Urban studies Institute.

Lawson, T., Rogerson, R., \& Barnacle, M. (2018). A comparison between the cost effectiveness of CCTV and improved street lighting as a means of crime reduction. Computers, Environment and Urban Systems, 68, 17-25.

Lee, J. S., Park, S., \& Jung, S. (2016). Effect of Crime Prevention through Environmental Design (CPTED) measures on active living and fear of crime. Sustainability, 8, 16.

Lett, D., Hier, S. P., \& Walby, K. (2010). CCTV surveillance and the civic conversation: A study in public sociology. The Canadian Journal of Sociology/Cahiers canadiens de sociologie, $35,437-462$.

Lindgren, T., \& Nilsen, M. R. (2012). Safety in residential areas. Tijdschrift voor Economische en Sociale Geografie, 103, 196-208.

Liu, D., Song, W., \& Xiu, C. (2016). Spatial patterns of violent crimes and neighborhood characteristics in Changchun, China. Australian and New Zealand Journal of Criminology, 49, 53-72.

Loomis, D., Marshall, S. W., Wolf, S. H., Runyan, C. W., \& Butts, J. D. (2002). Effectiveness of safety measures recommended for prevention of workplace homicide. Journal of the American Medical Association, 287, 1011-1017.

Lorenc, T., Petticrew, M., Whitehead, M., Neary, D., Clayton, S., Wright, K. Renton, A. (2013). Environmental interventions to reduce fear of crime: systematic review of effectiveness. Systemic Reviews, 2, 30.

Loukaitou-sideris, A. (1999). Hot spots of bus stop crime: The importance of environmental attributes. Journal of the American Planning Association, 65(4), 395-411.

Loukaitou-Sideris, A. (2012). Safe on the move: The importance of the built environment. In V. Ceccato (Ed.), The Urban Fabric of Crime and Fear (pp. 85-110). Dordrecht: Springer Netherlands.

Loukaitou-Sideris, A. (2014). Fear and safety in transit environments from the women's perspective. Security Journal, 27, 242-256.

Loukaitou-Sideris, A., \& Eck, J. E. (2007). Crime prevention and active living. American Journal of Health Promotion, 21 (4 suppl), 380-389. 
Loukaitou-Sideris, A., Liggett, R., \& Iseki, H. (2002). The geography of transit crime: Documentation and evaluation of crime incidence on and around the Green Line stations in Los Angeles. Journal of Planning Education and Research, 22, 135-151.

Loukaitou-Sideris, A., \& Stieglitz, O. (2002). Children in Los Angeles Parks: A study of equity, quality and children's satisfaction with neighbourhood parks. The Town Planning Review, 73, 467-488.

Lum, C., Stoltz, M., Koper, C., \& Scherer, J. A. (2019). Research on body-worn cameras. Criminology \& Public Policy, 18, 93-118.

Luymes, D. (1997). The fortification of suburbia: Investigating the rise of enclave communities. Landscape and Urban Planning, 39, 187-203.

Marselle, M., Wootton, A. B., \& Hamilton, M. G. (2012). A design against crime intervention to reduce violence in the night-time economy. Security Journal, 25, 116-133.

Marzbali, M. H., Abdullah, A., Abd Razak, N., \& Tilaki, M. J. M. (2012). The relationship between socio-economic characteristics, victimization and CPTED principles: Evidence from the MIMIC model. Crime Law and Social Change, 58, 351-371.

Matijosaitiene, I. (2016). Combination of CPTED and space syntax for the analysis of crime. Safer Communities, 15, 49-62.

Mears, D. P., Scott, M. L., \& Bhati, A. S. (2007). A process and outcome evaluation of an agricultural crime prevention initiative. Criminal Justice Policy Review, 18, 51-80.

Merry, S. E. (1981). Defensible space undefended: Social factors in crime control through environmental design. Urban Affairs Review, 16, 397-422.

Monchuk, L. (2011). The way forward in designing out crime? Greater Manchester police design for security consultancy. Safer Communities, 10, 31-40.

Moher, D., Liberati, A., Tetzlaff, J., \& Altman, D. (2009). Preferred reporting items for systematic reviews and meta-analyses: the PRISMA statement. PLoS Med, 6(7), e1000097. doi:doi:10.1371/journal.pmed1000097.

Myhre, M., \& Rosso, F. (Eds.). (1996). Designing for Security in Meteor: A Projected New Metro Line in Paris (Vol. 6). Monsey, NY: Willow Tree.

Nasar, J. L., \& Bokharaei, S. (2017). Impressions of lighting in public squares after dark. Environment and Behavior, 49, 227-254.

Németh, J. (2012). Controlling the commons: How public is public space? Urban Affairs Review. 48, 811-835.

Newton, A. (2008). A study of bus route crime risk in urban areas: The changing environs of a bus journey. Built Environment (1978-), 34(1), 88-103.

Newton, A. D., Johnson, S. D., \& Bowers, K. J. (2004). Crime on bus routes: An evaluation of a safer travel initiative. Policing: An International Journal of Police Strategies o Management, 27, 302-319.

Nikunen, H., \& Korpela, K. M. (2012). The effects of scene contents and focus of light on perceived restorativeness, fear and preference in nightscapes. Journal of Environmental Planning and Management, 55, 453-468.

Owusu, G., Wrigley-Asante, C., Oteng-Ababio, M., \& Yaa Owusu, A. (2015). Crime Prevention Through Environmental Design (CPTED) and built-environmental manifestations in Accra and Kumasi, Ghana. Crime Prevention and Community Safety, 17, 249-269.

Pain, R., MacFarlane, R., \& Turner, K. (2006). 'When, where, if, and but': Qualifying GIS and the effect of streetlighting on crime and fear. Environment and Planning AEconomy and Space, 38, 2055-2074.

Pain, R. H. (1997). Social geographies of women's fear of crime. Transactions of the Institute of British Geographers, 22, 231-244. 
Pain, R. and Smith, S. J. (2008). Fear, critical geopolitics and everyday life. In Pain. R \& Smith, S.J. (Eds), Fear: Critical Geopolitics And Everyday Life (pp. 1-24). Aldershot: Ashgate.

Painter, K., \& Farrington, D. P. (1994). The crime reducing effect of improved street lighting: The Dudley Project. In R. V. Clarke (Ed.), Situational Crime PreventionSuccessful Case Studies (pp. 209-226). USA: Lynne Rienner Publishers.

Park, M., Perez, N., Jennings, W. G., \& Gover, A. R. (2017). A preliminary examination of the role of deterrence and target hardening on future recidivism risk among burglars in South Korea. Security Journal, 30, 903-921.

Patino, J. E., Duque, J. C., Pardo-Pascual, J. E., \& Ruiz, L. A. (2014). Using remote sensing to assess the relationship between crime and the urban layout. Applied Geography, 55, 48-60.

Peek-Asa, C., \& Casteel, C. H. (2010). Documenting the need for translational research: An example from workplace violence prevention. Injury Prevention, 16, 50-52.

Perkins, C., Steinbach, R., \& Tompson, L. (2015). What is the effect of reduced street lighting on crime and road traffic injuries at night? A mixed-methods study. Southampton (UK). Public Health Research, 3(11).

Piza, E. L., Welsh, B. C., Farrington, D. P., \& Thomas, A. L. (2019). CCTV surveillance for crime prevention. Criminology \& Public Policy, 18, 135-159.

Poyner, B. (1991). Situational crime prevention in two parking facilities. In R. V. Clarke (Ed.), Situational Crime Prevention-Successful Case Studies (pp. 157-166). USA: Lynne Rienner Publishers.

Poyner, B. (1994). An evaluation of walkway demolition on a British housing estate. In R. V. Clarke (Ed.), Situational Crime Prevention-Successful Case Studies (pp. 59-73). USA: Lynne Rienner Publishers.

Poyner, B., \& Webb, B. (1987). Reducing theft from shopping bags in city center markets. In R. V. Clarke (Ed.), Situational Crime Prevention-Successful Case Studies (pp. 83-89). USA: Lynne Rienner Publishers.

Quinet, K. D., \& Nunn, S. (1998). Illuminating crime: The impact of street lighting on calls for police service. Evaluation Review, 22, 751-779.

Rankavat, S., \& Tiwari, G. (2016). Pedestrians risk perception of traffic crash and built environment features-Delhi, India. Safety Science, 87, 1-7.

Ratcliffe, J. H., Taniguchi, T., \& Taylor, R. B. (2009). The crime reduction effects of public CCTV cameras: A multi-method spatial approach. Justice Quarterly, 26, 746-770.

Reynald, D. M. (2011). Translating CPTED into crime preventive action: A critical examination of CPTED as a tool for active guardianship. European Journal on Criminal Policy and Research, 17, 69-81.

Robinson, M. B., \& Robinson, C. E. (1997). Environmental characteristics associated with residential burglaries of student apartment complexes. Environment and Behavior, 29, 657-675.

Rogers, C. (2005). Gate expectations: Initial findings from a crime and disorder prevention initiative. Safer Communities, 4, 19-22.

Rogers, C. (2007). Alley-gates: Theory and practice-A perspective from urban south wales. Crime Prevention and Community Safety, 9, 179-200.

Saleh, A. S., Saif, N. I., \& Sartawi, K. S. (2015). CPTED and workplace violence in Jordanian public hospitals. Asian Social Science, 11, 336-347.

Sanders, C. B., \& Hannem, S. (2012). Policing "the risky": Technology and surveillance in everyday patrol work. Canadian Review of Sociology, 49, 389-410.

Santos, J. R. (2020). Decoding (sub)urban-rural fragmentation processes: A morphogenetic approach in Lisbon metropolis In A. K.-F. a. A. Djukić (Ed.), Handbook of 
Research on Urban-Rural Synergy Development Through Housing, Landscape, and Tourism (p. 434). Hershey, PA: IGI Global.

Saville, G. (2009). SafeGrowth: Moving forward in neighbourhood development. Built Environment (1978-), 35, 386-402.

Saville, G. (2013). Third Generation of CPTED. www.alternation.ca (accessed 18 October 2019).

Schaefer, L., \& Mazerolle L. (2017). Predicting perceptions of crime: Community residents' recognition and classification of local crime problems. Australian \& New Zealand Journal of Criminology, 51, 183-203.

Schaefer, L., \& Mazerolle, L. (2018). Predicting perceptions of crime: Community residents' recognition and classification of local crime problems. Australian and New Zealand Journal of Criminology, 51, 183-203.

Seo, S. Y., \& Lee, K. H. (2017). Effects of changes in neighbourhood environment due to the CPTED project on residents' social activities and sense of community: A case study on the Cheonan Safe Village Project in Korea. International Journal of Urban Sciences, 21, 326-343.

Shamsuddin, S., \& Hussin, N. A. (2013). Implementation of crime prevention through environmental design by Kuala Lumpur city hall. In N. Xu, L. Tian, \& F. Dai (Eds.), Sustainable Cities Development and Environment Protection, Pts 1-3 (Vol. 361-363, pp. 193+). Durnten-Zurich: Trans Tech Publications Ltd.

Skudder, H., Brunton-Smith, I., Tseloni, A., McInnes, A., Cole, J., Thompson, R., \& Druckman, A. (2018). Can burglary prevention be low-carbon and effective? Investigating the environmental performance of burglary prevention measures. Security Journal, 31, 111-138.

Smith, M. J., \& Clarke, R. V. (2000). Crime and public transport. Crime and Justice, 27, $169-233$.

Smith, N., \& Low, S. (Eds.) (2013). The Politics of Public Place. London, New York: Routledge.

Squires, G. D. (1992). From Redlining to Reinvestment: Community Response to Urban Disinvestment. Philadelphia: Temple University Press.

Srisuwan, A. (2011). Street lighting design for a traditional city: A case study of Jesi, Italy. Proceedings of the Conference Light 2011, 121. www.witpress.com/elibrary/ wit-transactions-on-the-built-environment/121/22051 (accessed 20 February 2020).

Stamps III, A. E. (2005). Enclosure and safety in urbanscapes. Environment and Behavior, 37, 102-133.

Stolzenberg, L., D'Alessio, S. J., \& Flexon, J. L. (2017). A hunter's moon: The effect of moon illumination on outdoor crime. American Journal of Criminal Justice, 42, 188-197.

Sugino, H., \& Arima, T. (2014). Spatial vulnerability and district resilience for the next generation of CPTED: A case study of crime preventive spatial design targeting arson. International Review for Spatial Planning and Sustainable Development, 2, 23-41.

Sutton, A., \& Wilson, D. (2004). Open-street CCTV in Australia: The politics of resistance and expansion. Surveillance \& Society, 2, 310-322.

Takizawa, A., Koo, W., \& Katoh, N. (2010). Discovering distinctive spatial patterns of snatch theft in Kyoto City with CAEP. Journal of Asian Architecture and Building Engineering, 9, 103-110.

Tanulku, B. (2018). The formation and perception of safety, danger and insecurity inside gated communities: Two cases from Istanbul, Turkey. Journal of Housing and the Built Environment, 33, 151-173.

Taylor, B., Koper, C., \& Woods, D. (2012). Combating vehicle theft in Arizona: A randomized experiment with license plate recognition technology. Criminal Justice Review, 37, 24-50. 
Tjernberg, C., \& Granhag, F. (2019). Kamerabevakning som brottsförebyggande åtgärd: Ett evidensbaserat beslutsstöd samt vägledning. Västra Götalands länsstyrelsen, www. lansstyrelsen.se/download/18.26f506e0167c605d56942223/1551356889287/ brottsforebyggande-arbete-kameraovervakning.pdf (accessed 16 February 2020).

Tjoa, P. F., \& Devon, R. (2010). Safety by design: A review on planning and design strategies for a safer living environment in higher education communities. World Transactions on Engineering and Technology Education, 8, 301-309.

Tseng, C. H., Duane, J., \& Hadipriono, F. (2004). Performance of campus, parking garages in preventing crime. Journal of Performance of Constructed Facilities, 18, $21-28$.

Uittenbogaard, A., \& Ceccato, V. (2014). Safety in Stockholm's underground stations: An agenda for action. European Journal on Criminal Policy and Research, 20, 73-100.

Uittenbogaard, A., \& Ceccato, V. (2015). Temporal and spatial patterns of suicides in Stockholm's subway stations. Accident Analysis \& Prevention, 81, 96-106.

Vagi, K. J., Stevens, M. R., Simon, T. R., Basile, K. C., Carter, S. P., \& Carter, S. L. (2018). Crime Prevention Through Environmental Design (CPTED) characteristics associated with violence and safety in middle schools. Journal of School Health, $88,296-305$.

van Eck, N. J., \& Waltman, L. (2019). VOSviewer version 1.6.12. Leiden: Leiden University. Retrieved from www.vosviewer.com (accessed 20 February 2020).

van Rijswijk, L., \& Haans, A. (2018). Illuminating for safety: Investigating the role of lighting appraisals on the perception of safety in the urban environment. Environment and Behavior, 50, 889-912.

Vernez Moudon, A., Bassok, A., \& Kang, M. (2018). Safe from Crime at LocationSpecific Transit Facilities (No. WA-RD 882.1). Washington (State). Department of Transportation. Research Office.

Weisheit, R. A., \& Donnermeyer, J. F. (2000). Change and continuity in crime. Criminal Justice, 1, 309-357.

Welsh, B. C., \& Farrington, D. P. (2004). Evidence-based crime prevention: The effectiveness of CCTV. Crime Prevention and Community Safety, 6, 21-33.

Welsh, B. C., \& Farrington, D. P. (2009). Public area CCTV and crime prevention: An updated systematic review and meta-analysis. Justice Quarterly, 26, 716-745.

White, R. (1993). Youth and the conflict over urban space. Children's Environments, $10(1), 85-93$.

Wikström, P. O., \& Treiber, K. (2017). Beyond risk factors: an analytical approach to crime prevention. In B. M. E. Teasdale (Ed.), Preventing Crime and Violence. Advances in Prevention Science. Cham: Springer.

Williams, D., \& Ahmed, J. (2009). The relationship between antisocial stereotypes and public CCTV systems: Exploring fear of crime in the modern surveillance society. Psychology, Crime and Law, 15, 743-758.

Williams, K. S., \& Johnstone, C. (2000). The politics of the selective gaze: Closed circuit television and the policing of public space. Crime, Law and Social Change, 34, $183-210$.

Wilson, J. Q., \& Kelling, G. L. (1982). Broken windows. Atlantic Monthly, 249, 29-38.

Winge, S., \& Knutsson, J. (2003). An evaluation of the CCTV scheme at Oslo central railway station. Crime Prevention and Community Safety, 5, 49-59.

Yavuz, N., \& Welch, E. W. (2010). Addressing fear of crime in public space: Gender differences in reaction to safety measures in train transit. Urban Studies, 47, 2491-2515.

Zahm, D. (2005). Learning, translating and implementing CPTED. Journal of Architectural and Planning Research, 22, 284-293. 


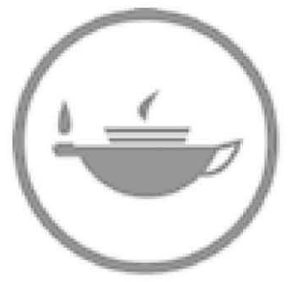

Taylor \& Francis Taylor \& Francis Group

http://taylorandfrancis.com 